\title{
Dynamics of greenhouse gases in groundwater: hydrogeological and hydrogeochemical controls
}

\author{
Olha Nikolenko ${ }^{\mathrm{a}, \mathrm{b}, *}$, Philippe Orban ${ }^{\mathrm{a}}$, Anna Jurado ${ }^{\mathrm{a}, 1}$, Cedric Morana ${ }^{\mathrm{b}, \mathrm{c}}$, Pierre Jamin ${ }^{\mathrm{a}}$, \\ Tanguy Robert $^{\mathrm{a}, \mathrm{d}}$, Kay Knöller ${ }^{\mathrm{e}}$, Alberto V. Borges ${ }^{\mathrm{b}}$, Serge Brouyère ${ }^{\mathrm{a}}$ \\ ${ }^{a}$ University of Liège, Urban and Environmental Engineering Research Unit, Hydrogeology and Environmental Geology, Aquapôle, 4000, Liège, Belgium \\ ${ }^{\mathrm{b}}$ Chemical Oceanography Unit, University of Liège, Liège, Belgium \\ ${ }^{\mathrm{c}}$ Department of Earth and Environmental Sciences, KU Leuven, Leuven, 3001, Belgium \\ ${ }^{\mathrm{d}}$ F.R.S.-FNRS (Fonds de la Recherche Scientifique), 1000, Bruxelles, Belgium \\ ${ }^{\mathrm{e}}$ Department of Catchment Hydrology, UFZ Helmholtz-Centre for Environmental Research, Halle, Germany
}

\section{A R T I C L E I N F O}

Editorial handling by Elisa Sacchi

Keywords:

Greenhouse gases (GHGs)

Groundwater

Indirect emissions

Agriculture

Stable isotope analysis

\begin{abstract}
A B S T R A C T
In this study the variability of greenhouse gases (GHGs) concentrations along lateral and vertical dimensions of the chalk aquifer located in the eastern part of Belgium was examined in order to understand its dependence on hydrogeological and hydrogeochemical conditions. Groundwater samples from 29 wells/piezometers were analyzed for concentrations of nitrous oxide $\left(\mathrm{N}_{2} \mathrm{O}\right)$, carbon dioxide $\left(\mathrm{CO}_{2}\right)$, methane $\left(\mathrm{CH}_{4}\right)$, major and minor elements and stable isotopes of nitrate $\left(\mathrm{NO}_{3}{ }^{-}\right)$, nitrous oxide $\left(\mathrm{N}_{2} \mathrm{O}\right)$, sulfate $\left(\mathrm{SO}_{4}{ }^{2-}\right)$ and boron (B). For lateral investigations, four zones with different environmental settings were identified (southern, central, north-eastern and northern). Groundwater was oversaturated with GHGs with respect to its equilibrium concentrations with the atmosphere in all zones, except the northern one, undersaturated in $\mathrm{N}_{2} \mathrm{O}(0.07 \pm 0.08 \mu \mathrm{gN} / \mathrm{L} \mathrm{vs.} 0.3 \mu \mathrm{gN} / \mathrm{L})$. Vertical dimension studies showed the decrease in $\mathrm{CO}_{2}$ concentration and significant changes in both isotope signatures and concentration of $\mathrm{N}_{2} \mathrm{O}$ with depth. The production of $\mathrm{N}_{2} \mathrm{O}$ could be attributed to a combination of nitrification and denitrification processes occurring at different depths. $\mathrm{CO}_{2}$ concentration is controlled by the process of dissolution of carbonate minerals which constitute aquifer geology. $\mathrm{CH}_{4}$ is produced due to methanogenesis in deeper parts of the aquifer, though its thermogenic origin is also possible. Differences in hydrogeochemical settings and changing intensity of biogeochemical processes across the area and with depth have considerable effect on GHGs concentrations. Thus, before estimating GHGs fluxes at the groundwater-river interface insights obtained from larger-scale investigations are required in order to identify the representative spatial zones which govern GHGs emissions.
\end{abstract}

\section{Introduction}

Due to the rising concern about global climate change, significant research efforts have been devoted to the refinement of the estimates of GHGs budgets (Mosier et al., 1998; Kroeze et al., 2005; Denman et al., 2007; Battin et al., 2009; Syakila \& Kroeze et al., 2011; IPCC, 2013). Contributing to these research efforts, several studies have persuasively argued that it is essential to better understand and accurately quantify the contribution of groundwater to $\mathrm{N}_{2} \mathrm{O}, \mathrm{CO}_{2}$ and $\mathrm{CH}_{4}$ emissions at the groundwater - surface water interface (indirect emissions) (Worrall and Lancaster, 2005; Johnson et al., 2008; Minamikawa et al., 2010; Jahangir et al., 2012; Borges et al., 2015; Jurado et al., 2018a). Particular attention should be paid to GHGs fluxes via aquatic pathways in the agricultural catchments, since it is assumed that their fluxes in such ecosystems could be increased due to intensive applications of chemical fertilizers and manure as well as peculiarities of land cultivation (Wilcock and Sorrell, 2008; Smith, 2010; Kindler et al., 2011; Anderson et al., 2014).

So far, research studies have been mainly concentrated on: 1) obtaining better insight into the processes and factors that control the dynamics of GHGs (Clough et al., 2007; Koba et al., 2009; Macpherson, 2009; Well et al., 2012; Bunnell-Young et al., 2017) and 2) calculation of GHGs emissions from aquifers in different ecosystems with contrasting land use and hydrogeochemical conditions (Weymann et al., 2008; Butterbach-Bahl and Well, 2010; Laini et al., 2011; Vilain et al., 2012). While addressing the first question, for instance, von der Heide

\footnotetext{
* Corresponding author. Bât. B52/3, Hydrogeology and Environmental Geology, Quartier Polytech 1, allée de la Découverte 9, 4000, Liège 1, Belgium.

E-mail addresses: nikolenko_olha@ukr.net,o.nikolenko@uliege.be (O. Nikolenko), serge.brouyere@uliege.be (S. Brouyère).

${ }^{1}$ Present Address: Institute for Groundwater Management, Technische Universität Dresden, Dresden, Germany.
} 


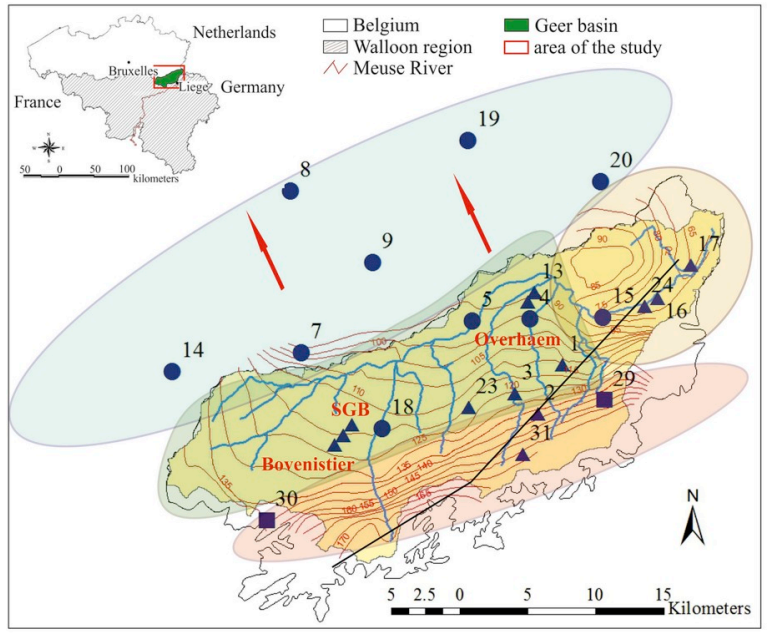

Legend:
southern zone
central zone
north-eastern zone
northern zone
limit of the hydrological basin
limit of the hydrogeological basin
rivers
isopieses
direction of the
groundwater flow
- the Horion-Hozémont fault

private well

A piezometer

pumping well
Fig. 1. Map of the studied area in the Geer basin showing river network, isopieses, direction of groundwater flow and sampling points (wells and piezometers). Colors indicate different zones used to aggregate data. (For interpretation of the references to colour in this figure legend, the reader is referred to the Web version of this article.) et al. (2008) examined the influence of land use on GHGs fluxes in the subsurface and compared the contributions of autotrophic and heterotrophic denitrification into resulting $\mathrm{N}_{2} \mathrm{O}$ fluxes; Minamikawa et al. (2010) concentrated on the influence of different cropping systems and hydrological regimes; Jahangir et al. (2013) studied the impact of geochemical conditions (DO, Eh, pH, availability of electron donors DOC or reduced $\mathrm{Fe}^{2+} / \mathrm{S}^{2-}$ ), hydrological activity and biological factors. While addressing the second question, Hiscock et al. (2003) compared estimates of $\mathrm{N}_{2} \mathrm{O}$ emission based on the Intergovernmental Panel on Climate Change (IPCC) methodology and using the hydrogeological data; Jurado et al. (2018b) calculated indirect emission of GHGs from groundwater at the regional scale in Wallonia (Belgium) using the IPCC methodology.

Nevertheless, large uncertainties remain associated with quantification of groundwater fluxes of $\mathrm{CO}_{2}, \mathrm{CH}_{4}$ and $\mathrm{N}_{2} \mathrm{O}$ and it remains a significant source of uncertainty in the global GHGs budgets (Weymann et al., 2008; Minamikawa et al., 2010; Jahangir et al., 2012). Firstly, many studies so far have focused on the GHGs production and consumption in the soil profile and calculated the estimated groundwater GHGs fluxes using the concentrations of these gases in the subsoil (Beaulieu et al., 2011). Secondly, there are difficulties related to the upscaling of point estimates of GHGs concentrations in groundwater to larger scale and longer time periods while taking into account the spatiotemporal variability of their fluxes. For example, Vilain et al. (2012) calculated annual groundwater $\mathrm{N}_{2} \mathrm{O}$ flux in the Orgeval catchment (France) extrapolating the data obtained from 3 piezometers, which could be a rough estimate for heterogeneous landscapes considered on the broader scale. It is important to constrain and better understand the scope of uncertainties related to the upscaling procedures. That is why the studies devoted to the distribution and dynamics of GHGs in groundwater should consider the variability in hydrogeology, hydrogeochemistry and land use across the explored area (Choi et al., 2010; Cooper et al., 2017).

This study attempts to improve the understanding how the interplay between hydrogeological and hydrogeochemical controls considered at the catchment scale could influence groundwater contribution into GHG emissions via rivers. To this end, it focuses on analysis of experimental data obtained during the regional sampling campaign conducted to explore the distribution of GHGs in the subsurface in a Cretaceous fractured chalk aquifer extending across the border between Wallonia and Flanders in Eastern Belgium.

In our study we hypothesize that: 1) the magnitude of GHGs fluxes depends on the distribution of $\mathrm{N}$ and $\mathrm{C}$ sources across the different hydrogeochemical zones and in relation to groundwater flow patterns rather than absolute values of nitrogen $(\mathrm{N})$ and carbon $(\mathrm{C})$ loading to groundwater; 2) estimates of the intensity of GHGs production/consumption processes within the aquifer and their contribution to GHGs emission at the groundwater-river interface should be based on largescale investigations which provide the opportunity to get better insight into their spatial controls.

In order to test these hypotheses this study attempts to: 1) explore the variability of GHGs concentration along groundwater flow paths taking into account spatial changes in hydrogeochemical, hydrogeological and land management conditions; 2) identify the sources of $\mathrm{N}$ and $\mathrm{C}$ loads across the aquifer; 3 ) reveal the processes that govern the biogeochemistry of GHGs under different environmental settings. The obtained information will help to understand how the GHG fluxes occurring on the groundwater-river interface depend on catchment-scale dynamics of biogeochemical process of their production and consumption.

\section{Materials and methods}

\subsection{Study site}

The studied aquifer is located in Cretaceous chalky geological formations in the eastern part of Belgium. While the southern part of the aquifer is unconfined, the northern part is confined under Tertiary clayey sediments. Subsurface flow is from the South to the North and the aquifer is mainly drained by the Geer river (Goderniaux et al., 2011). Semi-confined conditions may be observed under the Geer alluvial deposits close to the river. The piezometric map for the area (Fig. 1) shows that groundwater discharges into the Geer River in its downstream part.

The basis of the aquifer is represented with the layer of smectite clay which is assumed to be of low hydraulic conductivity (Orban, 2010). Below the clay layer, the Houiller formation (sandstones and shales with embedded coal beds) occurs (Boulvain, 2008). The area is characterized with the presence of series of faults causing the fracturing of chalk, among which the major one is the Horion-Hozémont fault.

The aquifer is recharged by infiltration of rainfall through the overlying loess and the residual conglomerate (Orban et al., 2006). The estimated annual recharge rate is between 175 and $275 \mathrm{~mm} / \mathrm{y}$. Since the thick loess layer (up to $20 \mathrm{~m}$ ) and unsaturated chalky zone (up to $15 \mathrm{~m}$ ) located above the aquifer control its recharge, the resulting water fluxes at the groundwater table are smoothed, and seasonal fluctuations of hydraulic heads are attenuated, which can be more concisely observed on the multiannual scale (Brouyère et al., 2004). The recharge zone of the chalk aquifer mostly corresponds to the hydrological basin of the Geer River - tributary of the Meuse River.

The studied area is predominantly characterized with agricultural land use (nearly 65\%). Agricultural activities are the largest source of the nitrate input into groundwater, followed by domestic wastewater effluents (Dautrebande and Sohier, 2004). 
The chalk aquifer is one of the most exploited groundwater bodies in the Walloon Region, with about $60,000 \mathrm{~m}^{3}$ groundwater withdrawal per day, which are used, in particular, to satisfy the drinking water needs of the city of Liège and its suburbs (Orban, 2010). Groundwater is abstracted from the aquifer using $45 \mathrm{~km}$ of drainage galleries and pumping wells that belong to water supply companies. Groundwater consumers are divided between the following sectors: the public water sector $(87 \%)$, the industrial sector $(12 \%)$ and the agriculture and services (1\%) (Hérivaux et al., 2013).

\subsection{Sampling network}

The sampling campaign intended to explore the distribution of GHGs within the chalk aquifer. To this end, groundwater samples from 29 wells were collected. The sampling network included existing wells across the aquifer that were selected considering hydrogeological conditions along the main groundwater flow path from the South to the North and taking into account the level of urbanization pressure (Fig. S1 of the supporting information). Consequently, after exploring the resulting groundwater sampling network and considering the results of previous investigations conducted within the area of the study by Hakoun et al. (2017), the selected wells were grouped into 4 zones taking into account the differences in hydrogeochemistry, hydrogeology and urbanization level (Fig. 1): 1) southern zone - unconfined conditions and the most urbanized land use; 2) central zone - unconfined conditions and predominantly agricultural activity; 3) northeastern zone - zone of groundwater recharge to the Geer river and predominantly agricultural land use (though sampling wells were located close to the urban areas); and 4) northern zone - confined conditions and mixed land use pattern. In total, the monitoring network included 9 pumping wells ( 6 of them located in the confined part of the area), 2 private wells and 18 piezometers (Fig. 1). All these sampling points are screened in the chalk aquifer, at depths varying from $16 \mathrm{~m}$ to $70 \mathrm{~m}$ (mean $39 \mathrm{~m}$ ) in the unconfined part of the aquifer in the South, and from $51 \mathrm{~m}$ to $120 \mathrm{~m}$ (mean $80 \mathrm{~m}$ ) in the confined part of the aquifer in the North. In addition, three of the sampling locations (Bovenistier, SGB and Overhaem, located in the central and north-eastern zones) are equipped with multilevel piezometers that provided the opportunity to sample groundwater at different depths (Table 2).

\subsection{Groundwater sampling}

Groundwater sampling was accomplished between the 14th and 23rd of August 2017. Before the start of sampling, wells/piezometers were purged until stabilization of field parameters $(\mathrm{pH}$, conductivity, temperature, dissolved oxygen) or by pumping three times the volume of the water present in the wellbore (including gravel pack). The samples collected in the field for the analyses of the GHGs, major and minor ions, dissolved organic carbon (DOC), metals and stable isotopes were put on the ice inside a field refrigerator and transported to the laboratory at the end of the sampling day. In addition, in-situ measurements of $\mathrm{pH}$, electrical conductivity (EC, $\mu \mathrm{S} / \mathrm{cm}$ ), dissolved oxygen $(\mathrm{DO}, \mathrm{mg} / \mathrm{L})$ and temperature $\left({ }^{\circ} \mathrm{C}\right)$ were conducted using a portable multimeter HQ40d (HACH), with a closed flow cell inside which the measuring probes were immersed.

Groundwater for the analyses of dissolved $\mathrm{N}_{2} \mathrm{O}$ and $\mathrm{CH}_{4}$ was collected into $50 \mathrm{ml}$ borosilicate serum vials (two replicates per location), preserved by addition of $200 \mu \mathrm{L}$ of saturated $\mathrm{HgCl}_{2}$ and sealed using a butyl rubber stopper and an aluminum seal. To measure the partial pressure of $\mathrm{CO}_{2}\left(\mathrm{pCO}_{2}\right)$, four polypropylene syringes of $60 \mathrm{ml}$ were filled. The samples for major and minor ions were stored in $180 \mathrm{ml}$ polypropylene bottles preventing the contact with atmospheric oxygen. For estimation of the concentration of DOC, groundwater was filtered through $0.22 \mu \mathrm{m}$ polyethylsulfone filters, stored in $40 \mathrm{ml}$ borosilicate vials and poisoned with $100 \mu \mathrm{L}$ of $\mathrm{H}_{3} \mathrm{PO}_{4}$ (45\%). Groundwater for the analysis of metals was filtered through a $0.45 \mu \mathrm{m}$ polyethersulphone and microquartz fiber filter into $125 \mathrm{~mL}$ polypropylene vials and acidified with $1 \mathrm{ml}$ of $12 \mathrm{~N} \mathrm{HCl}$ for sample preservation.

Groundwater for ${ }^{15} \mathrm{~N}$ and ${ }^{18} \mathrm{O}$ isotopes of $\mathrm{N}_{2} \mathrm{O}$ was sampled into $250 \mathrm{~mL}$ borosilicate serum bottles (two replicates per location), preserved by addition of $400 \mu \mathrm{L}$ of saturated $\mathrm{HgCl}_{2}$, sealed with a butyl stopper and crimped with an aluminum cap. For ${ }^{15} \mathrm{~N}$ and ${ }^{18} \mathrm{O}$ of $\mathrm{NO}_{3}{ }^{-}$, the samples were collected into $60 \mathrm{ml}$ polypropylene vials, preceded by filtration of the samples through the $0.22 \mu \mathrm{m}$ nylon filters. For ${ }^{34} \mathrm{~S}$ and ${ }^{18} \mathrm{O}$ isotopes of $\mathrm{SO}_{4}{ }^{2-}, 1 \mathrm{~L}$ of groundwater was collected into a polyethylene bottle and stabilized with $100 \mathrm{ml}$ of zinc acetate solution (3\%). Groundwater samples for ${ }^{11} \mathrm{~B}$ isotopes were collected into $60 \mathrm{ml}$ polypropylene bottles.

\subsection{Analytical methods}

The analyses of groundwater samples for major and minor ions were performed at the Hydrogeology Laboratory of the University of Liège (Belgium). The concentrations of major $\left(\mathrm{Na}^{+}, \mathrm{Mg}^{2+}, \mathrm{K}^{+}, \mathrm{Cl}^{-}, \mathrm{SO}_{4}{ }^{2-}\right.$ and $\left.\mathrm{NO}_{3}{ }^{-}\right)$and minor ions $\left(\mathrm{NO}_{2}{ }^{-}\right.$and $\left.\mathrm{NH}_{4}{ }^{+}\right)$were analyzed by means of aqueous phase ion chromatography via specific ion exchange resin and a conductivity detector. The concentration of $\mathrm{Ca}^{2+}$ and total alkalinity were measured by potentiometric titration in the laboratory.

The concentrations of dissolved $\mathrm{N}_{2} \mathrm{O}$ and $\mathrm{CH}_{4}$ were measured at the Chemical Oceanography Unit of the University of Liège (Belgium) with the headspace equilibration technique $\left(25 \mathrm{ml}\right.$ of $\mathrm{N}_{2}$ headspace in $50 \mathrm{ml}$ serum bottles) and a gas chromatograph equipped with electron capture and flame ionization detectors (SRI 8610 GC-ECD-FID), as described in detail by Borges et al. (2015). The SRI 8610 GC-ECD-FID was calibrated with $\mathrm{CH}_{4}: \mathrm{CO}_{2}: \mathrm{N}_{2} \mathrm{O}: \mathrm{N}_{2}$ mixtures (Air Liquide Belgium) of 0.2, 2.0 and $6.0 \mathrm{ppm} \mathrm{N}_{2} \mathrm{O}$ and of 1,10 and $30 \mathrm{ppm} \mathrm{CH}_{4}$. The $\mathrm{pCO}_{2}$ was directly determined in the field using an infra-red gas analyzer (Li-Cor Li-840) by creating a headspace with ambient air in polypropylene syringes (1:1 ratio of water and air). The Li-Cor Li-840 was calibrated with a suite of $\mathrm{CO}_{2}: \mathrm{N}_{2}$ mixtures (Air Liquide Belgium) with mixing ratios of 388, 813, 3788 and $8300 \mathrm{ppm} \mathrm{CO}_{2}$.

The stable isotope analyses of $\mathrm{N}_{2} \mathrm{O}$ were conducted using an off-axis cavity ringdown spectroscopy (OA-ICOS) (Los Gatos Research) instrument for the measurements of $\delta^{15} \mathrm{~N}^{\alpha}, \delta^{15} \mathrm{~N}^{\beta}, \delta^{18} \mathrm{O}$ of $\mathrm{N}_{2} \mathrm{O}$ at the Chemical Oceanography Unit of the University of Liège (Belgium), and the ${ }^{15} \mathrm{~N}$-site preference (SP, in \%) was calculated as the difference between $\delta^{15} \mathrm{~N}^{\alpha}$ and $\delta^{15} \mathrm{~N}^{\beta}\left(\delta^{15} \mathrm{~N}^{\alpha}-\delta^{15} \mathrm{~N}^{\beta}\right)$. A $20 \mathrm{ml}$ helium (He) headspace was created in the $250 \mathrm{ml}$ bottles $\sim 24 \mathrm{~h}$ before the analysis in order to assure equilibration between gas and dissolved $\mathrm{N}_{2} \mathrm{O}$. Prior to the measurement of the headspace samples, the instrument was warmed and conditioned by a flow-through calibration using a standard gas mix of $\mathrm{N}_{2} \mathrm{O}$ : synthetic air (4 ppm) during $\sim 30 \mathrm{~min}$. This gas cylinder had been calibrated by Tokyo Institute of Technology $\left(\delta^{15} \mathrm{~N}_{\mathrm{AIR}}{ }^{\alpha}=0.47 \% 0 \pm 0.20 \% ; \quad \delta^{15} \mathrm{~N}_{\mathrm{AIR}}{ }^{\beta}=\right.$ $1.41 \% 0 \pm 0.26 \%$; $\delta^{18}$ Ovsmow $=37.63 \%$ $\pm 0.18 \%$ ) . Headspace samples were injected into a custom-built purge and trap device (He flow: $120 \mathrm{ml} \mathrm{min}^{-1}$ ) consisting of a $\mathrm{CO}_{2}$ trap (soda lime), a water trap (magnesium perchlorate) and a stainless steel loop immersed in liquid nitrogen to trap $\mathrm{N}_{2} \mathrm{O} .5 \mathrm{~min}$ after sample injection, the loop was isolated from the rest of the system by switching the position of 3-way valves (Swagelok), warmed at room temperature, and connected to the instrument to inject the sample. Volume of headspace injection was adapted as function of the $\mathrm{N}_{2} \mathrm{O}$ concentration in every sample in order to minimize any concentration-dependent effect (Wassenaar et al., 2018). Data were calibrated against standard gas mix (see above) injection following the approach of Wassenaar et al. (2018) using the purge and trap setup. The utilization of this purge and trap device helped to avoid the possible interference from $\mathrm{CO}_{2}, \mathrm{H}_{2} \mathrm{O}$ (trapped) or $\mathrm{CH}_{4}$ (flow through the loop) and allowed to minimize difference in gas matrix composition between different types of samples and the standard.

The isotope analyses of $\mathrm{NO}_{3}{ }^{-}$and $\mathrm{SO}_{4}{ }^{2-}$ were carried out at the Helmholtz Center for Environmental Research (Department of Catchment Hydrology, Halle, Germany). Nitrogen $\left(\delta^{15} \mathrm{~N}\right)$ and oxygen 
$\left(\delta^{18} \mathrm{O}\right)$ isotope analyses of $\mathrm{NO}_{3}{ }^{-}$were performed using a G-IRMS (gas isotope ratio mass spectrometer) DELTA $\mathrm{V}$ plus connected to a GasBench II from Thermo using the denitrifier method that converts all sampled $\mathrm{NO}_{3}{ }^{-}$to $\mathrm{N}_{2} \mathrm{O}$ (Sigman et al., 2001; Casciotti et al., 2003). In order to determine the $\delta^{34} \mathrm{~S}$ and $\delta^{18} \mathrm{O}$ of $\mathrm{SO}_{4}{ }^{2-}$, the dissolved $\mathrm{SO}_{4}{ }^{2-}$ in groundwater samples was precipitated as $\mathrm{BaSO}_{4}$ by adding $0.5 \mathrm{M} \mathrm{BaCl}_{2}$. The $\delta^{34} \mathrm{~S}-\mathrm{SO}_{4}{ }^{2-}$ was measured after converting $\mathrm{BaSO}_{4}$ to $\mathrm{SO}_{2}$ using an elemental analyzer (continuous flow flash combustion technique) coupled with a G-IRMS (delta S, ThermoFinnigan, Bremen, Germany). The analysis of $\delta^{18} \mathrm{O}-\mathrm{SO}_{4}{ }^{2-}$ on $\mathrm{BaSO}_{4}$ was conducted by high temperature pyrolysis at $14500^{\circ} \mathrm{C}$ in a TC/EA connected to a delta plus XL spectrometer G-IRMS (ThermoFinnigan, Bremen, Germany). The notation was expressed in terms of delta $(\delta)$ per mil relative to the international standards for all the stable isotopes (V-SMOW for $\delta^{18} \mathrm{O}$ of $\mathrm{NO}_{3}{ }^{-}, \mathrm{AIR}_{2} \mathrm{~N}_{2}$ for $\delta^{15} \mathrm{~N}$ of $\mathrm{NO}_{3}{ }^{-}$, V-CDT for $\delta^{34} \mathrm{~S}$ of $\mathrm{SO}_{4}{ }^{2-}$ and V-PDB for $\delta^{18} \mathrm{O}$ of $\mathrm{SO}_{4}{ }^{2-}$ ). The reproducibility of the samples was $\pm 0.4 \%$ for $\delta^{15} \mathrm{~N} ; \pm 1.6 \%$ for $\delta^{18} \mathrm{O}$ of $\mathrm{NO}_{3}{ }^{-} ; \pm 0.3 \%$ for $\delta^{34} \mathrm{~S}$, and $\pm 0.5 \%$ for $\delta^{18} \mathrm{O}$ of $\mathrm{SO}_{4}{ }^{2-}$. The isotope results represent the mean value of the true double measurements of each sample.

The concentration and stable isotope composition of DOC were analyzed at the department of Earth and Environmental Sciences of the Katholieke Universiteit Leuven. Samples analysis was carried out with an IO Analytical Aurora $1030 \mathrm{~W}$ (persulfate oxidation) coupled to a Thermo delta V advantage IRMS as described in Morana et al. (2015). Quantification of DOC concentration and correction of its stable isotope composition was performed against IAEA-CH6 and an internally calibrated sucrose standard $\left(\delta^{13} \mathrm{C}=-26.99 \% 0 \pm 0.04 \% 0\right)$. Typical reproducibility for DOC analysis was on the order of $<5 \%$.

\subsection{Data analysis}

\subsubsection{Descriptive analysis}

This study explores the distribution of GHGs concentrations in the subsurface from two perspectives: in lateral and vertical dimensions. While analyzing the lateral distribution, it attempts to demonstrate the variability of GHGs concentrations along the groundwater flow, which helps to reveal factors and processes controlling the distribution of $\mathrm{N}_{2} \mathrm{O}$, $\mathrm{CO}_{2}$ and $\mathrm{CH}_{4}$ in groundwater across four spatial zones characterized with contrasting hydrogeological and hydrogeochemical conditions. The analysis focusing on vertical dimension investigates the possible impact of variations in hydrogeochemical conditions with depth on GHGs dynamics. While exploring the distribution of GHGs concentrations in both dimensions, this study considers the same set of chemical and isotope parameters used to identify and characterize $\mathrm{N}$ and $\mathrm{C}$ sources and GHGs production/consumption processes (see sections 3.1.1 and 3.1.2.). Moreover, during the analysis of groundwater chemistry the concentrations of such major ions as $\mathrm{Na}^{+}, \mathrm{Cl}^{-}$and $\mathrm{SO}_{4}{ }^{2-}$ were included alongside with $\mathrm{NO}_{3}{ }^{-}$, since they are the most frequently used water pollution/anthropogenic impact indicators (Yakovlev et al., 2015).

\subsubsection{Statistics}

For the purposes of data analysis in course of this study, Kohonen's Self-Organizing Map method (SOM) was applied using the Matlab software (Vesanto et al., 2000). This approach allows projecting multidimensional data on a two-dimensional grid and capturing complex (nonlinear) relationships between variables (Peters et al., 2007). In this study, it was used to develop maps of individual component planes and identify clusters within the obtained experimental dataset. The visual comparison of derived individual component planes provided an opportunity to reveal the statistical relationships between the analyzed variables, while k-means clustering on SOM allowed exploring the data properties in more detail, as it enables separating the dataset into different groups of similar hydrogeochemical features (Gamble and
Babbar-Seben, 2012). Moreover, Pearson correlation and linear regression analyses were carried out with R software.

\subsubsection{Isotopomer and isotope maps}

Isotopomer and isotope mapping approach is used in hydrogeochemical studies to identify sources of $\mathrm{N}$ in the aquifer and characterize its subsurface dynamics (Koba et al., 2009; Well et al., 2012; Clagnan et al., 2018; Jurado et al., 2018b). For our study, $\delta^{15} \mathrm{~N}-\mathrm{NO}_{3}{ }^{-}$ (\%o) versus $\delta^{18} \mathrm{O}-\mathrm{NO}_{3}^{-}(\% 0)$ and $\delta^{15} \mathrm{~N}-\mathrm{NO}_{3}^{-}(\% 0)$ versus $\delta^{11} \mathrm{~B}(\% 0)$ isotope maps were used in order to distinguish sources of $\mathrm{N}$ input to the aquifer. At the same time, $\Delta \delta^{15} \mathrm{NNO}_{3}{ }^{-}-\mathrm{N}_{2} \mathrm{O}(\%)$ versus SP (site preference) (\%) isotopomer map, $\delta^{15} \mathrm{~N}-\mathrm{N}_{2} \mathrm{O}$ (\%o v. AIR) versus $\delta^{18} \mathrm{O}-\mathrm{N}_{2} \mathrm{O}$ (\%o v. VSMOW) and $\delta^{34} \mathrm{~S}-\mathrm{SO}_{4}{ }^{2-}$ versus $\delta^{18} \mathrm{O}-\mathrm{SO}_{4}{ }^{2-}$ maps were applied in order to identify the $\mathrm{N}_{2} \mathrm{O}$ production-consumption processes.

The $\Delta \delta^{15} \mathrm{~N}_{\mathrm{NO}^{-}}{ }^{-}$- N2O (\%) versus SP (site preference) (\%o) isotopomer map was developed taking into account $\Delta \delta^{15} \mathrm{~N}_{\mathrm{NO}^{3}}{ }^{-}$- $\mathrm{N} 2 \mathrm{O}$ ranges for nitrification and denitrification processes proposed by Koba et al. (2009), and references therein, and SP intervals reported by Lewicka-Szczebak et al. (2017), and references therein. The second one, plotting $\delta^{15} \mathrm{~N}-\mathrm{N}_{2} \mathrm{O}$ (\%o v. AIR) versus $\delta^{18} \mathrm{O}-\mathrm{N}_{2} \mathrm{O}$ (\%o v. VSMOW), was created considering $\delta^{18} \mathrm{O}-\mathrm{N}_{2} \mathrm{O}$ nitrification and denitrification ranges provided by Snider et al. (2012), Snider et al. (2013) and Rosamond (2013). The $\delta^{15} \mathrm{~N}-\mathrm{N}_{2} \mathrm{O}$ values corresponding to denitrification and nitrification processes were calculated using equations proposed by Zou et al. (2014), assuming that $\mathrm{NH}_{4}{ }^{+}$fertilizers, sewage and manure were the main sources of $\mathrm{NO}_{3}{ }^{-}$and $\mathrm{NH}_{4}{ }^{+}$in groundwater (the ranges of the sources were taken from the literature review provided by Nikolenko et al. (2017)):

1) bacterial denitrification:

$\delta^{15} N_{N 2 O}=\varepsilon_{N O 3 \rightarrow N 2 O}+\delta^{15} N_{N O 3}$

2) bacterial nitrification:

$\delta^{15} N_{N 2 O}=\varepsilon_{N H 3 \rightarrow N 2 O}+\delta^{15} N_{N H 4}$

The enrichment factors $(\varepsilon)$ for these processes were taken from previous pure culture studies: $\varepsilon_{N O 3 \rightarrow N 2 O}=-45 \%$ to $-10 \%$ (Snider et al., 2009 and references therein) for bacterial denitrification; $\varepsilon_{N H 3 \rightarrow N 2 O}=-66 \%$ to $-36.8 \%$ (Yoshida, 1988; Sutka et al., 2006; Snider et al., 2009; Li et al., 2014) for bacterial nitrification.

\section{Results}

3.1. Variability of hydrogeochemical parameters and isotopes across the chalk aquifer

\subsubsection{Lateral dimension}

According to the Piper diagram, the majority of collected groundwater samples fell into the range typical for $\mathrm{Ca}-\mathrm{HCO}_{3}$ water type (Fig. $\mathrm{S} 2$ of the supporting information), though several points located in the southern zone corresponded to the $\mathrm{Ca}-\mathrm{HCO}_{3}-\mathrm{Cl}$ type. The decrease in EC was observed from the south to the north: $980 \pm 87 \mu \mathrm{S} / \mathrm{cm}$ in the southern zone, $803 \pm 87 \mu \mathrm{S} / \mathrm{cm}$ in the central zone, $794 \pm 32 \mu \mathrm{S} / \mathrm{cm}$ in the north-eastern zone and $717 \pm 97 \mu \mathrm{S} / \mathrm{cm}$ in the northern zone. The $\mathrm{pH}$ values varied from 6.77 to 7.23 across the aquifer. The concentration of DOC was lower than $2 \mathrm{mg} / \mathrm{L}$ at each of the sampled locations. The variability in hydrogeochemical and isotopic composition of groundwater between four spatial zones of the area of study is summarized in Figures S3 to S8 of the supporting information and Table 1 .

In general, the decrease in the concentration of major ions and GHGs was observed from the South to the North along the groundwater flow. The highest concentrations of major ions and dissolved GHGs 
Table 1

Hydrogeochemical and isotopic composition (mean value \pm standard deviation) of groundwater in the chalk aquifer across spatial zones (see Fig. 1 ).

\begin{tabular}{|c|c|c|c|c|}
\hline Parameter & Southern zone & Central zone & North-eastern zone & Northern zone \\
\hline $\mathrm{DO}(\mathrm{mg} / \mathrm{L})$ & $6.3 \pm 2.3$ & $9.4 \pm 0.6$ & $5.9 \pm 2.6$ & $1.5 \pm 2.1$ \\
\hline $\mathrm{NO}_{3}{ }^{-}(\mathrm{mg} / \mathrm{L})$ & $60.7 \pm 8.9$ & $38.8 \pm 8.1$ & $29.1 \pm 9.0$ & $0.2 \pm 0.4$ \\
\hline $\mathrm{Na}^{+}(\mathrm{mg} / \mathrm{L})$ & $30.1 \pm 12.3$ & $12.1 \pm 2.5$ & $14.8 \pm 3.8$ & $11.4 \pm 3.1$ \\
\hline $\mathrm{Cl}^{-}(\mathrm{mg} / \mathrm{L})$ & $73.1 \pm 30.2$ & $51.7 \pm 7.2$ & $44.4 \pm 7.8$ & $15.1 \pm 10.3$ \\
\hline $\mathrm{SO}_{4}^{2-}(\mathrm{mg} / \mathrm{L})$ & $113.9 \pm 45.9$ & $51.7 \pm 17.5$ & $38.5 \pm 6.9$ & $39.4 \pm 27.1$ \\
\hline B $(\mu \mathrm{g} / \mathrm{L})$ & $22.3 \pm 17.0$ & $10.7 \pm 3.3$ & $23.3 \pm 6.7$ & $39.8 \pm 18.5$ \\
\hline $\mathrm{N}_{2} \mathrm{O}(\mu \mathrm{g} \mathrm{N} / \mathrm{L})$ & $14.6 \pm 3.2$ & $4.9 \pm 1.5$ & $5.2 \pm 2.1$ & $0.07 \pm 0.08$ \\
\hline $\mathrm{pCO}_{2}(\mathrm{ppm})$ & $34032 \pm 9799$ & $24097 \pm 3201$ & $28552 \pm 3327$ & $28662 \pm 4824$ \\
\hline $\mathrm{CH}_{4}(\mu \mathrm{g} / \mathrm{L})$ & $0.4 \pm 0.5$ & $0.6 \pm 0.8$ & $0.9 \pm 1.6$ & $19.5 \pm 25.8$ \\
\hline$\delta^{15} \mathrm{~N}-\mathrm{N}_{2} \mathrm{O}(\% 0)$ & $14.7 \pm 3.1$ & $11.9 \pm 5.6$ & $10.2 \pm 5.1$ & not available \\
\hline$\delta^{18} \mathrm{O}-\mathrm{N}_{2} \mathrm{O}(\%)$ & $+38.7 \pm 3.1$ & $+36.9 \pm 14.4$ & $+31.5 \pm 9.6$ & not available \\
\hline$\delta^{15} \mathrm{~N}-\mathrm{NO}_{3}^{-}(\% 0)$ & $+6.5 \pm 3.5$ & $+5.1 \pm 0.7$ & $+6.1 \pm 1.1$ & not available \\
\hline$\delta^{18} \mathrm{O}-\mathrm{NO}_{3}^{-}(\% 0)$ & $+2.5 \pm 1.5$ & $+0.9 \pm 3.1$ & $2.4 \pm 3.6$ & not available \\
\hline$\delta^{34} \mathrm{~S}-\mathrm{SO}_{4}^{2-}(\% 0)$ & $+0.6 \pm 0.3$ & $+0.3 \pm 0.5$ & $1.7 \pm 1.5$ & $18.1 \pm 6.7$ \\
\hline$\delta^{18} \mathrm{O}-\mathrm{SO}_{4}^{2-}(\%)$ & $+3.3 \pm 2.1$ & $+2.2 \pm 0.7$ & $+1.9 \pm 1.3$ & $+5.7 \pm 3.1$ \\
\hline$\delta^{11} \mathrm{~B}(\%)$ & $+28.0 \pm 20.0$ & $+10.7 \pm 7.2$ & $+15.1 \pm 6.8$ & $+9.4 \pm 4.4$ \\
\hline$\delta^{13} \mathrm{C}-\mathrm{DOC}(\% \mathrm{)})$ & $-34.1 \pm 3.4$ & $-35.5 \pm 3.4$ & $-36.9 \pm 3.9$ & $-32 \pm 2.8$ \\
\hline$\delta^{2} \mathrm{H}-\mathrm{H}_{2} \mathrm{O}(\%)$ & $-49.2 \pm 1.4$ & $-49.4 \pm 0.7$ & $-50.3 \pm 0.2$ & $-50.1 \pm 1.6$ \\
\hline$\delta^{18} \mathrm{O}-\mathrm{H}_{2} \mathrm{O}(\% 0)$ & $-7.5 \pm 0.1$ & $-7.6 \pm 0.1$ & $-7.7 \pm 0.1$ & $-7.7 \pm 0.2$ \\
\hline
\end{tabular}

(except $\mathrm{CH}_{4}$ ) were detected in the most urbanized southern zone, and the lowest - in the confined northern zone. In the majority of groundwater samples collected from all three zones located in the unconfined part of the aquifer the concentrations of $\mathrm{N}_{2} \mathrm{O}$ exceeded the equilibrium with ambient atmosphere concentration $(0.3 \mu \mathrm{gN} / \mathrm{L}$ ) (Hasegawa et al., 2000). On the contrary, groundwater from the northern, confined, zone appeared to be undersaturated with respect to $\mathrm{N}_{2} \mathrm{O}$ concentration. At the same time, the concentrations of dissolved $\mathrm{CH}_{4}$ were higher than the equilibrium with ambient atmosphere concentration $(0.05 \mu \mathrm{g} / \mathrm{L})$ (Bell et al., 2017) in all of the locations, with the highest concentration detected in the northern zone. The $\mathrm{pCO}_{2}$ did not vary significantly between the different zones, with groundwater being supersaturated with $\mathrm{CO}_{2}$ across the whole area of the study (the atmospheric equilibrium of $\mathrm{CO}_{2}$ is approximately $400 \mathrm{ppm}$ ).

Due to the low concentration of $\mathrm{NO}_{3}{ }^{-}$and $\mathrm{N}_{2} \mathrm{O}$ in the northern zone, it was not possible to measure their isotopic signatures in the samples collected there. At the same time, the data obtained from three other zones showed that the isotopic values of $\mathrm{N}_{2} \mathrm{O}$ varied from $-18.6 \%$ to $-3.8 \%$ of $\delta^{15} \mathrm{~N}$ and from +14.7 to $+42.6 \%$ for $\delta^{18} \mathrm{O}$. As for the isotopic signals of $\mathrm{NO}_{3}{ }^{-}$, they covered the interval from $+3.8 \%$ to $+8 \%$ for $\delta^{15} \mathrm{~N}$ and from $-6.6 \%$ o to $+4.7 \%$. $\delta^{34} \mathrm{~S}-\mathrm{SO}_{4}{ }^{2-}$ was characterized with the most negative values in the northern zone, while southern and central zones exhibited values slightly above $0 \%$. $\delta^{18} \mathrm{O}-\mathrm{SO}_{4}{ }^{2-}$ did not change significantly between different zones and varied from approximately $+2 \%$ in central and north-eastern zones to $+5.7 \%$ in the northern zone. The highest values of ${ }^{11} \mathrm{~B}$ were detected in the southern and north-eastern zones, while the lowest - in the northern zone. $\delta^{13} \mathrm{C}$-DOC values were similar across all zones, and varied in the interval from $-41.8 \%$ to $-28.8 \%$. The isotopic signatures of $\delta^{2} \mathrm{H}-\mathrm{H}_{2} \mathrm{O}(\%)$ and $\delta^{18} \mathrm{O}-\mathrm{H}_{2} \mathrm{O}(\%)$ varied insignificantly between the four zones.

\subsubsection{Vertical dimension}

The hydrogeochemical conditions in the aquifer might also significantly vary with depth. To evaluate if this variability had an influence on the fate of GHGs in the subsurface, groundwater samples were collected from collocated piezometers screened at different depths at Bovenistier, Overhaem and SGB sites. The data about the hydrogeochemistry and isotopic composition of groundwater along the three vertical profiles are compiled in Table 2.

$\mathrm{N}_{2} \mathrm{O}$ tended to accumulate in higher quantities in the shallow groundwater at Bovenistier and SGB sites, while at Overhaem its highest concentration was detected in the middle part of the aquifer.
For all of the locations the high concentration of $\mathrm{N}_{2} \mathrm{O}$ coincided with the high concentration of $\mathrm{NO}_{3}{ }^{-}$. The highest $\mathrm{N}_{2} \mathrm{O}$ content $(14-15 \mu \mathrm{N}$ / L) was revealed at Overhaem, where high $\mathrm{NO}_{3}{ }^{-}$and low level of DO were detected. In all of the cases the amount of dissolved $\mathrm{CO}_{2}$ was the highest in the shallowest part of the aquifer. In Bovenistier the concentrations of $\mathrm{CH}_{4}$ were higher in the locations with the lower concentrations of $\mathrm{DO}, \mathrm{NO}_{3}{ }^{-}$and $\mathrm{SO}_{4}{ }^{2-}$, which decreased with the depth. At Overhaem the concentration of $\mathrm{CH}_{4}$ did not change noticeably between different depth intervals. And SGB showed the highest concentrations of $\mathrm{CH}_{4}$ among the three studied vertical profiles, with its highest values detected at the shallowest and the deepest sampling locations. In general, in all of the groundwater samples collected from the multilevel piezometers the concentration of $\mathrm{N}_{2} \mathrm{O}, \mathrm{CO}_{2}$ and $\mathrm{CH}_{4}$ exceeded the equilibrium with the ambient atmosphere concentration.

As for the trends in the variation of isotopic signatures of groundwater samples along the vertical profile, no clear tendency comprising all analyzed cases was revealed, which highlights the importance of local-scale variations in the hydrogeochemical conditions and suggests that resulting isotope signatures could be influenced by simultaneous occurrence of various biogeochemical processes at different depth levels (see section 4.3. for more details). The highest $\delta^{15} \mathrm{~N}-\mathrm{NO}_{3}{ }^{-}$isotopic signatures overall were detected in groundwater samples collected from Overhaem, which was also the only site that exhibited the positive value of $\delta^{15} \mathrm{~N}-\mathrm{N}_{2} \mathrm{O}$ (detected in the deepest piezometer). The noticeably negative value of $\delta^{34} \mathrm{~S}-\mathrm{SO}_{4}{ }^{2-}$ was detected in the deepest part of the aquifer in Bovenistier, where the low concentration of $\mathrm{N}_{2} \mathrm{O}$ did not allow to measure $\delta^{15} \mathrm{~N}-\mathrm{N}_{2} \mathrm{O}$ and $\delta^{18} \mathrm{O}-\mathrm{N}_{2} \mathrm{O} . \delta^{11} \mathrm{~B}$ values increased with depths both at Bovenistier and SGB sites, though this tendency was not confirmed for the Overhaem location.

\section{Discussion}

\subsection{Sources of $N$ and $C$ loading across the aquifer}

The sources of $\mathrm{N}$ within the aquifer were identified by analysis of isotopic signatures data, using the plots of $\delta^{15} \mathrm{~N}-\mathrm{NO}_{3}{ }^{-}$versus $\delta^{18} \mathrm{O}-\mathrm{NO}_{3}{ }^{-}, \delta^{15} \mathrm{~N}-\mathrm{NO}_{3}{ }^{-}$versus $\delta^{11} \mathrm{~B}$. At the same time, the origin of $\mathrm{C}$ loading was determined by analyzing the findings of conducted correlation analyses. Since within the distinguished four spatial zones with contrasting environmental settings the concentration of DOC did not vary significantly, it was expected that there would be no considerable differences regarding the sources of $\mathrm{C}$ compounds in the subsurface across the studied area. Therefore, the following section focuses at first 
Table 2

Hydrogeochemical and isotopic composition of groundwater in the chalk aquifer at the Bovenistier, Overhaem and SGB sites (see Fig. 1).

\begin{tabular}{|c|c|c|c|c|c|c|c|c|c|c|}
\hline \multirow[t]{4}{*}{ Site } & \multirow{2}{*}{$\begin{array}{l}\text { Name } \\
\text { Piezometer }\end{array}$} & \multicolumn{3}{|c|}{ Bovenistier } & \multicolumn{3}{|c|}{ Overhaem } & \multicolumn{3}{|c|}{ SGB } \\
\hline & & 28 & 27 & 26 & 12 & 11 & 10 & 21 & 22 & 25 \\
\hline & Type & shallow & medium & deep & shallow & medium & deep & shallow & medium & deep \\
\hline & Screen depth (m) & $28-32$ & $24-49$ & $46-51$ & $3-4$ & $10-11$ & $26-31$ & $9-16$ & $16-26$ & $30-40$ \\
\hline \multirow[t]{18}{*}{ Parameters } & $\mathrm{EC}(\mu \mathrm{S} / \mathrm{cm})$ & 955 & 859 & 564 & 1121 & 1068 & 909 & 765 & 752 & 665 \\
\hline & $\mathrm{pH}$ & 7.0 & 7.01 & 7.11 & 7.03 & 7.15 & 7.0 & 7.0 & 7.08 & 7.12 \\
\hline & $\mathrm{DO}(\mathrm{mg} / \mathrm{L})$ & 8.8 & 9.5 & 1.8 & 0.3 & 0.1 & 1.3 & 6.1 & 9.3 & 8.7 \\
\hline & $\mathrm{NO}_{3}{ }^{-}(\mathrm{mg} / \mathrm{L})$ & 60.9 & 51.3 & 4.2 & 23.3 & 36.9 & 11.4 & 43.4 & 38.1 & 27.4 \\
\hline & $\mathrm{Na}^{+}(\mathrm{mg} / \mathrm{L})$ & 14.8 & 14.0 & 6.7 & 92.5 & 52.6 & 21.1 & 10.9 & 10.6 & 8.2 \\
\hline & $\mathrm{Cl}^{-}(\mathrm{mg} / \mathrm{L})$ & 61.6 & 56.5 & 10.5 & 49.6 & 48.3 & 48.2 & 22.7 & 45.2 & 36.8 \\
\hline & $\mathrm{SO}_{4}{ }^{2-}(\mathrm{mg} / \mathrm{L})$ & 58.1 & 52.3 & 17.4 & 107.6 & 94.4 & 88.5 & 35.9 & 33.5 & 21.2 \\
\hline & B $(\mu \mathrm{g} / \mathrm{L})$ & 11.0 & 9.7 & 12.0 & 21.0 & 33.0 & 9.6 & 20.0 & 8.6 & 8.3 \\
\hline & $\mathrm{N}_{2} \mathrm{O}(\mu \mathrm{g} \mathrm{N} / \mathrm{L})$ & 8.5 & 7.4 & 0.7 & 8.5 & 15.1 & 14.2 & 9.2 & 5.1 & 4.6 \\
\hline & $\mathrm{pCO}_{2}(\mathrm{ppm})$ & 32540 & 27763 & 16947 & 48614 & 27896 & 29117 & 34454 & 25148 & 21253 \\
\hline & $\mathrm{CH}_{4}(\mu \mathrm{g} / \mathrm{L})$ & 0.09 & 0.17 & 0.19 & 0.21 & 0.19 & 0.39 & 0.59 & 0.19 & 0.60 \\
\hline & $\delta^{15} \mathrm{~N}-\mathrm{N}_{2} \mathrm{O}(\%)$ & -13.7 & -15.2 & not available & -20.3 & -29.1 & +2.0 & -24.9 & -14.5 & -6.2 \\
\hline & $\delta^{18} \mathrm{O}-\mathrm{N}_{2} \mathrm{O}(\%)$ & +38.2 & +32.8 & not available & +63.1 & +53.7 & +50.4 & +47.7 & +35.7 & +36.4 \\
\hline & $\delta^{15} \mathrm{~N}-\mathrm{NO}_{3}^{-}(\% \mathrm{o})$ & +6.1 & +5.8 & +4.5 & +30.6 & +10.2 & +6.9 & +7.7 & +4.9 & +4.8 \\
\hline & $\delta^{18} \mathrm{O}-\mathrm{NO}_{3}^{-}(\% 0)$ & -0.2 & +1.4 & -0.2 & +17.4 & +5.0 & +4.9 & +7.5 & +3.1 & +4.7 \\
\hline & $\delta^{34} \mathrm{~S}-\mathrm{SO}_{4}{ }^{2-}(\%)$ & +1.2 & +0.7 & -25.1 & +2.5 & +1.4 & -0.4 & +1.5 & +0.3 & +3.0 \\
\hline & $\delta^{18} \mathrm{O}-\mathrm{SO}_{4}^{2-}(\%)$ & +2.5 & +2.6 & +5.0 & +5.8 & +4.6 & +3.8 & +5.0 & +1.7 & +0.9 \\
\hline & $\delta^{11} \mathrm{~B}(\%)$ & +12.0 & +3.4 & +0.1 & +9.5 & +19.0 & +0.3 & +29.0 & +11.0 & +5.4 \\
\hline
\end{tabular}

a

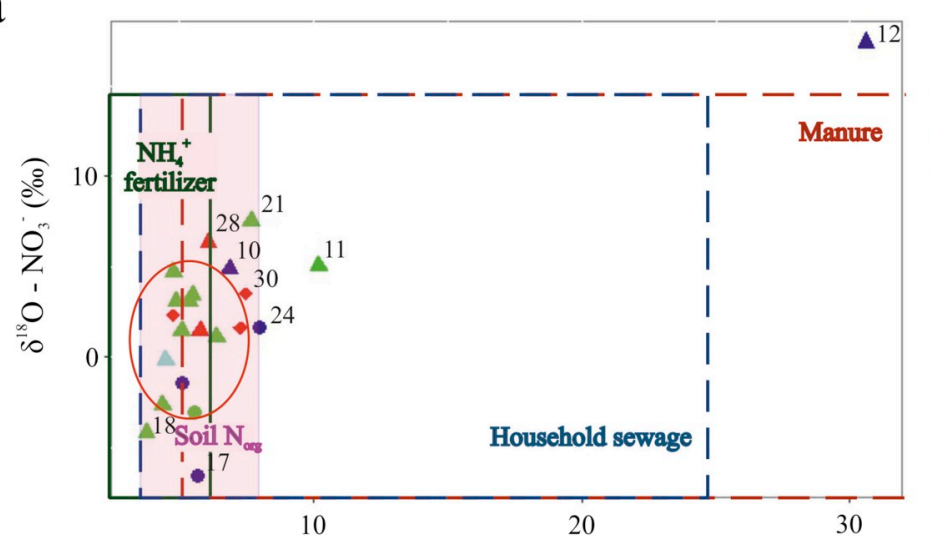

b

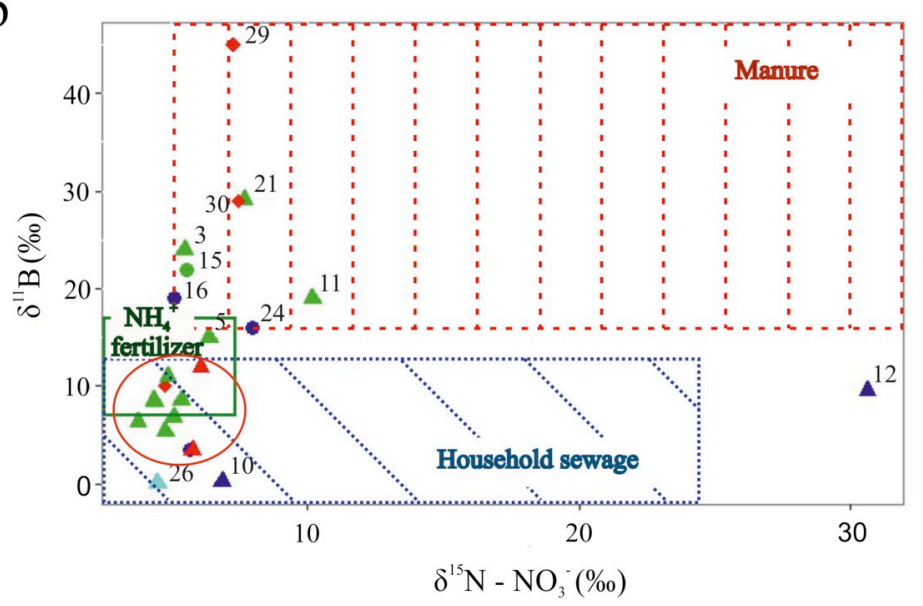

$\mathrm{NO}_{3}^{-}(\mathrm{mg} / \mathrm{L})$ :

$>50$

$25-50$

$10-25$

$<10$

Zones:

$\diamond$ southern

$\triangle$ central

north-eastern
Fig. 2. $\delta^{15} \mathrm{~N}$ versus $\delta^{18} \mathrm{O}$ values of $\mathrm{NO}_{3}{ }^{-}$(a) and $\delta^{15} \mathrm{~N}-\mathrm{NO}_{3}{ }^{-}$versus $\delta^{11} \mathrm{~B}(\mathrm{~b})$ of groundwater samples. The shape of the points shows affiliation to different zones presented in Fig. 1. Colors indicate different concentrations of $\mathrm{NO}_{3}{ }^{-}$in groundwater samples. The isotopic compositions for $\mathrm{NO}_{3}{ }^{-}$and $\mathrm{B}$ sources are derived from Michener and Lajtha (2008), Xue et al. (2009) and Widory et al. (2004). Areas in the red circles are zoomed and displayed in Fig. S9 of the supporting information. (For interpretation of the references to colour in this figure legend, the reader is referred to the Web version of this article.) 
on the analysis of the distribution of $\mathrm{N}$ sources across four spatial zones of the studied area, and afterwards considers the results of the correlation analyses elucidating origin of the $\mathrm{C}$ compounds in the subsurface.

The $\mathrm{NO}_{3}{ }^{-}$and $\mathrm{B}$ isotopic signatures of samples collected in the southern zone suggested the presence of several $\mathrm{NO}_{3}{ }^{-}$sources, including manure (locations 29 and 30 (see Fig. 1)) and $\mathrm{NH}_{4}{ }^{+}$fertilizers or soil organic $\mathrm{N}$ (point 2) (Fig. 2). In addition, $\mathrm{NO}_{3}{ }^{-}$fertilizers might also be considered as the possible primary source of $\mathrm{NO}_{3}{ }^{-}$in the groundwater, since once applied they can in part be turned into soil organic $\mathrm{N}$ and mobilized as $\mathrm{NO}_{3}{ }^{-}$later on due to the consequent ammonification and $\mathrm{NH}_{4}{ }^{+}$oxidation processes. The observed differences in sources of $\mathrm{N}$ input could be attributed to the fact that point 2 was located in close proximity to the agricultural areas.

In the central zone, $\mathrm{NO}_{3}{ }^{-}$and $\mathrm{B}$ isotopic signatures were in most cases close to the range typical for $\mathrm{NH}_{4}{ }^{+}$fertilizers. According to the data, sewage did not seem to be a dominant $\mathrm{N}$ source, except, likely, at Bovenistier location (points 26 and 27). Isotopic signal for manure was detected at point 3. Groundwater samples collected from multilevel piezometers at Overhaem (10,11 and 12) and SGB (21 and 25) exhibited the values which showed the simultaneous presence of two pollution sources: manure and sewage.

$\mathrm{NO}_{3}{ }^{-}$and $\mathrm{B}$ isotopic signatures of groundwater samples collected in the north-eastern zone suggested the presence of different types of pollution sources, namely manure (points 16, 15 and 24) and sewage (point 17).

As for the northern, confined zone of the aquifer, the concentrations of $\mathrm{N}$ compounds detected there were too low for analysis of $\mathrm{N}$ isotope composition and identification of pollution sources.

Pearson correlation analysis (Fig. S10 of the supporting information) indicated that carbonate minerals and organic matter were the principal sources of $\mathrm{C}$ compounds loading to subsurface system occurring across the area of study. In particular, the significant positive correlation between $\mathrm{CO}_{2}$ and $\mathrm{N}_{2} \mathrm{O}(\mathrm{r}=0.446, \mathrm{p}<0.05), \mathrm{CO}_{2}$ and $\mathrm{Ca}^{2+}(\mathrm{r}=0.473, \mathrm{p}<0.05), \mathrm{Ca}^{2+}$ and $\mathrm{NO}_{3}{ }^{-}(\mathrm{r}=0.707, \mathrm{p}<0.05)$, $\mathrm{Ca}^{2+}$ and $\mathrm{N}_{2} \mathrm{O}(\mathrm{r}=0.721, \mathrm{p}<0.05)$ indicated the link between concentrations of the inorganic $\mathrm{C}$ and $\mathrm{N}$ compounds, which suggested the ongoing dissolution of carbonates following water acidification due to the production of protons during nitrification or bacterial respiration activities (Laini et al., 2011; Fitts, 2002). Though the correlation between $\mathrm{CO}_{2}$ and DOC was non-significant $(\mathrm{r}=0.353, \mathrm{p}>0.05)$, the strong negative correlation which was observed between the $\delta^{13} \mathrm{C}-\mathrm{DOC}$ and DOC $(r=-0.42, p<0.05)$ showed that the decomposition of organic matter occurs.

In general, the results of the isotope analyses indicated clear difference in the origin of $\mathrm{NO}_{3}{ }^{-}, \mathrm{B}$ and $\mathrm{SO}_{4}{ }^{2-}$ between the northern zone, corresponding to the confined part of the aquifer, and three other zones, located in the unconfined part of the aquifer. Among the zones which belong to the unconfined part of the aquifer, it was the southern and north-eastern zones, which demonstrated $\mathrm{NO}_{3}{ }^{-}$and $\mathrm{B}$ isotopic signatures associated with manure, which might have originated as the sewage from the residential areas or leakage from septic tanks. In the central zone, $\mathrm{NO}_{3}{ }^{-}$was likely derived in the vast majority of cases from mineral fertilizers. In addition, $\mathrm{NO}_{3}{ }^{-}$might have also partly originated from $\mathrm{NH}_{4}{ }^{+}$derived from soil mineralization processes, though the isotope signal of this source was muted by other large pollution sources. As for the sources of $\mathrm{C}$ in the subsurface, it was most likely derived partly from the dissolution of carbonate minerals, and partly from decomposition of organic matter.

\subsection{Biogeochemistry of $\mathrm{N}_{2} \mathrm{O}, \mathrm{CH}_{4}$ and $\mathrm{CO}_{2}$. Lateral dimension}

\subsection{1. $\mathrm{N}_{2} \mathrm{O}$ production/consumption processes}

In order to understand which processes govern the dynamics of $\mathrm{N}_{2} \mathrm{O}$ production and consumption processes in the chalk aquifer, the experimental data were interpreted using correlation analysis along with linear regression analysis, results of examination of $\delta^{34} \mathrm{~S}-\mathrm{SO}_{4}{ }^{2-}$ versus $\delta^{18} \mathrm{O}-\mathrm{SO}_{4}{ }^{2-}$ plot, self-organizing maps (SOMs), isotope and isotopomer maps.

The correlation analysis and linear regression were applied to the subset of data representing the sampling locations in the unconfined part of the studied aquifer (the southern, central and north-eastern zone) in order to identify the dominant processes of $\mathrm{N}$ production/ consumption occurring in this area.

Pearson correlation analysis (Fig. 3) revealed high positive correlation between SP and $\delta^{18} \mathrm{O}-\mathrm{N}_{2} \mathrm{O}(\mathrm{r}=0.7, \mathrm{p}<0.05)$, while linear regression indicated positive dependency with the slope of 0.3 between these variables, which according to Ostrom et al. (2007) (and references therein) should suggest the occurrence of incomplete denitrification in the aquifer (while the slopes close to 2.2 indicate the occurrence of $\mathrm{N}_{2} \mathrm{O}$ reduction in the absence of $\mathrm{N}_{2} \mathrm{O}$ production). However, the absence of correlation between $\delta^{15} \mathrm{~N}-\mathrm{NO}_{3}{ }^{-}$and $\mathrm{NO}_{3}{ }^{-}(\mathrm{r}=0.25, \mathrm{p}>0.05)$ and relationship between $\delta^{15} \mathrm{~N}-\mathrm{NO}_{3}^{-}$and $\delta^{18} \mathrm{O}-\mathrm{NO}_{3}{ }^{-}$ $\left(\mathrm{Y}=5.557+0.1212 \mathrm{X}, \mathrm{R}^{2}=0.105\right)$ does not support the hypothesis about ongoing denitrification, because this process should lead to a strong negative correlation between $\delta^{15} \mathrm{~N}-\mathrm{NO}_{3}{ }^{-}$and $\mathrm{NO}_{3}{ }^{-}$, and a slope of regression between $\delta^{15} \mathrm{~N}-\mathrm{NO}_{3}{ }^{-}$and $\delta^{18} \mathrm{O}-\mathrm{NO}_{3}{ }^{-}$ranging from 0.5 to 0.8 (Aelion et al., 2009; Minet et al., 2017). Pearson analysis also indicated strong positive correlation between the concentrations of $\mathrm{NO}_{3}{ }^{-}$ and $\mathrm{N}_{2} \mathrm{O}(\mathrm{r}=0.8, \mathrm{p}<0.5)$ and between SP and $\mathrm{N}_{2} \mathrm{O}(\mathrm{r}=0.6$, $\mathrm{p}<0.05$ ), which also does not support the occurrence of denitrification (Ostrom et al., 2007; Jurado et al., 2017), but rather indicate ongoing nitrification. Moreover, groundwater chemistry data from the unconfined part of the aquifer demonstrated that aerobic conditions prevail across the area of study (see section 3.1.1), which also supports the idea regarding occurrence of nitrification, and inhibition of denitrification. According to Wankel et al. (2006) and McMahon and Böhlke (2006), the occurrence of nitrification can be evidenced by the existence of correlation between $\delta^{18} \mathrm{O}-\mathrm{NO}_{3}{ }^{-}$and $\delta^{18} \mathrm{O}-\mathrm{H}_{2} \mathrm{O}$, while the absence of correlation, on the contrary, suggests ongoing denitrification. Nevertheless, as shown in Fig. 7, there was no correlation between $\delta^{18} \mathrm{O}-\mathrm{NO}_{3}{ }^{-}$and $\delta^{18} \mathrm{O}-\mathrm{H}_{2} \mathrm{O}(\mathrm{r}=0.1, \mathrm{p}>0.05)$. Moreover, the average theoretical $\delta^{18} \mathrm{O}-\mathrm{NO}_{3}{ }^{-}$nitrification values defined from the following equation (Aelion et al., 2009):

$\delta^{18} \mathrm{O}-\mathrm{NO}_{3}^{-}=2 / 3\left(\delta^{18} \mathrm{O}-\mathrm{H}_{2} \mathrm{O}\right)+1 / 3\left(\delta^{18} \mathrm{O}-\mathrm{O}_{2}\right)$

for the three unconfined zones of the studied aquifer (2.8 for the southern and central zones, and 2.7 for the north-eastern zone) were different from the obtained results of $\delta^{18} \mathrm{O}-\mathrm{NO}_{3}{ }^{-}$analyses (2.5 for the southern zone, 1 for the central zone and -2.4 for the north-eastern zone). However, it should be emphasized that the above equation is just a rough estimate, since isotope exchange of intermediates with water messes up the O-isotope signature (Casciotti et al., 2010).

Such mixed evidence regarding the ongoing $\mathrm{N}_{2} \mathrm{O}$ production/consumption processes, obtained from the application of statistical analysis to the data describing unconfined part of the aquifer, suggests that the occurrence and intensity of these processes vary throughout the aquifer across the zones with different environmental conditions.

The values of $\delta^{34} \mathrm{~S}-\mathrm{SO}_{4}{ }^{2-}$ versus $\delta^{18} \mathrm{O}-\mathrm{SO}_{4}{ }^{2-}$ isotopic signals were examined, since $\mathrm{SO}_{4}{ }^{2-}$ isotope measurements are a unique tool allowing to reveal the connection between denitrification and sulphide oxidation during autotrophic denitrification (Mayer, 2005). Fig. 4 shows the overlap between mineralization of organic matter and oxidation of sulphides processes in all three zones located in the unconfined part of the aquifer. However, exceptions from this trend were detected for two points in Overhaem (12 and 13), which fell into the range typical for anthropogenic sources, and one point in Bovenistier (26), which showed the values typical for sulphide oxidation. Samples from the northern zone showed $\mathrm{SO}_{4}{ }^{2-}$ isotope values reflecting sulphide oxidation (points 7 and 9). So, the dominant process of $\mathrm{SO}_{4}{ }^{2-}$ and, consequently, $\mathrm{N}$ transformation in three unconfined zones cannot be clearly identified.

Previous conclusions are supported by the examination of the 

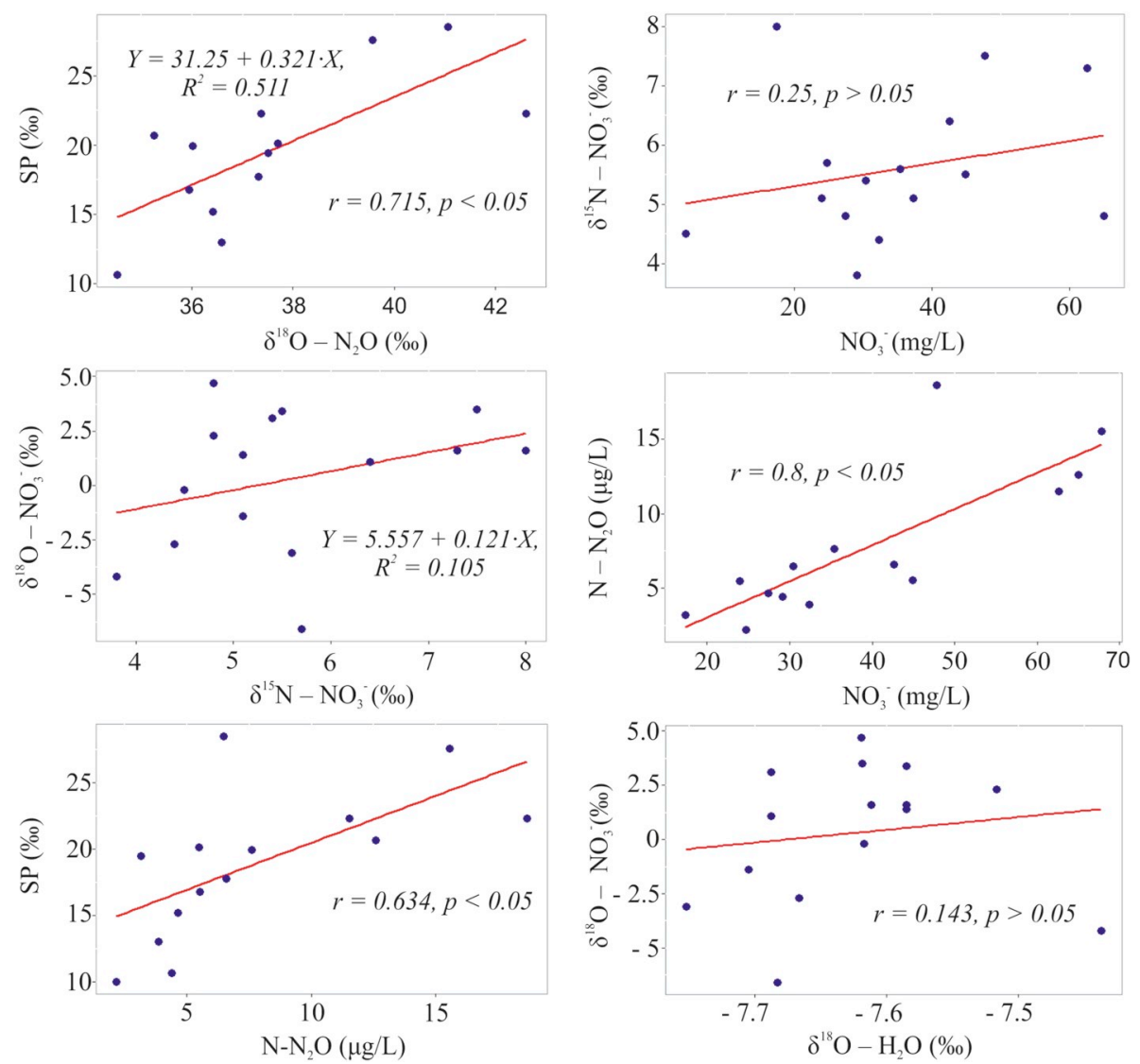

Fig. 3. The results of Pearson correlation and linear regression analyses for the subset. of data representing the unconfined part of the aquifer.

component matrices resulting from the SOM application to the dataset (Fig. 5). Visual inspection reveals clear positive correlation between concentrations of $\mathrm{Fe}, \mathrm{Mn}$ and $\mathrm{CH}_{4}$, which are negatively correlated with DO, thus indicating variations in oxido-reduction conditions across the aquifer. Results also show similar distribution patterns for $\mathrm{N}_{2} \mathrm{O}$ and $\mathrm{NO}_{3}{ }^{-}$, suggesting nitrification as the production mechanism of $\mathrm{N}_{2} \mathrm{O}$ in groundwater (Hiscock et al., 2003; Koba et al., 2009; Minamikawa et al., 2011). However, there is no clear relationship between $\mathrm{N}_{2} \mathrm{O}$ and DO, which does not allow claiming that nitrification is the only production pathway for $\mathrm{N}_{2} \mathrm{O}$. A positive correlation is also observed between SP and $\delta^{18} \mathrm{O}-\mathrm{N}_{2} \mathrm{O}$, which suggests the occurrence of denitrification (as $\mathrm{N}_{2} \mathrm{O}$ reduction proceeds), which leads to the simultaneous increase of both parameters (Well et al., 2005, 2012).

This evidence suggests that $\mathrm{N}_{2} \mathrm{O}$ production throughout the chalk aquifer could not be attributed unequivocally to one pathway, as none of them seems to be omnipresent and clearly dominant across the whole area under consideration. Therefore, it appears that intensity of $\mathrm{N}_{2} \mathrm{O}$ production/consumption processes might vary spatially both in lateral and vertical dimensions (i.e. the simultaneous occurrence of nitrification in the shallower part of the aquifer and denitrification in its deeper part).

In order to obtain better understanding into the spatial variability of subsurface processes, the clustering of the dataset was conducted by means of SOM, and the isotope signatures of samples belonging to

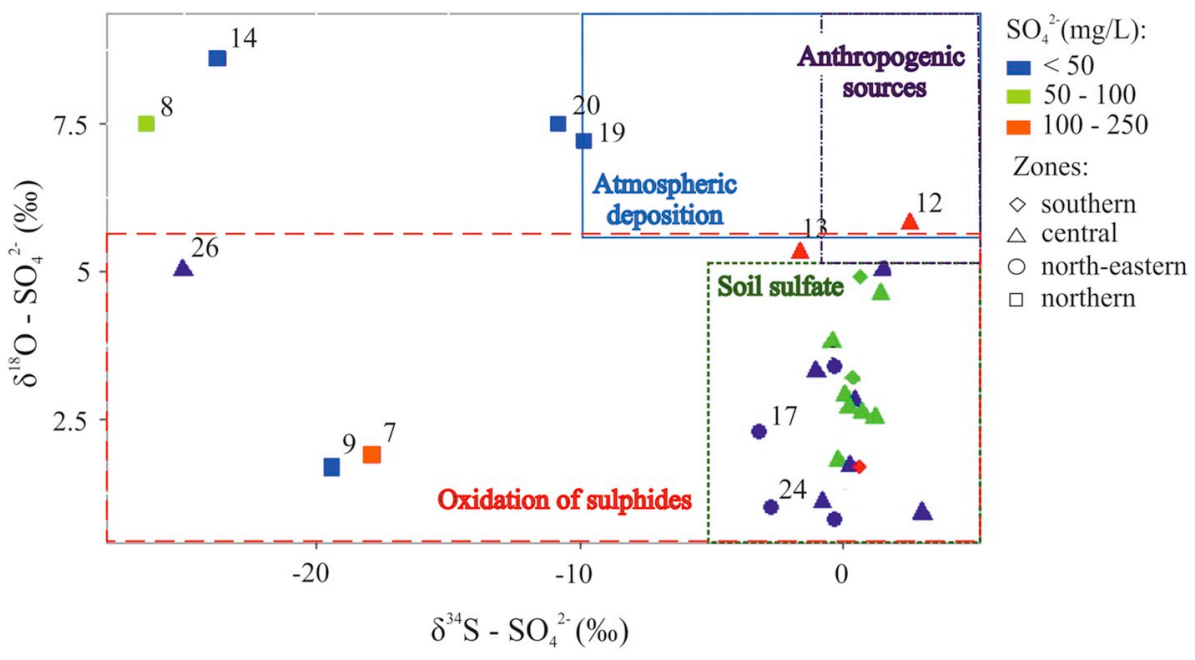

Fig. 4. $\delta^{34} \mathrm{~S}$ versus $\delta^{18} \mathrm{O}$ values of $\mathrm{SO}_{4}{ }^{2-}$ for groundwater samples. The shape of the points shows affiliation to different zones presented in Fig. 1. Colors indicate different concentrations of $\mathrm{SO}_{4}{ }^{2-}$ in groundwater samples. The isotopic compositions for the $\mathrm{SO}_{4}{ }^{2-}$ sources are derived from Krouse and Mayer (2000), Mayer (2005) and Knöller et al. (2005). (For interpretation of the references to colour in this figure legend, the reader is referred to the Web version of this article.) 

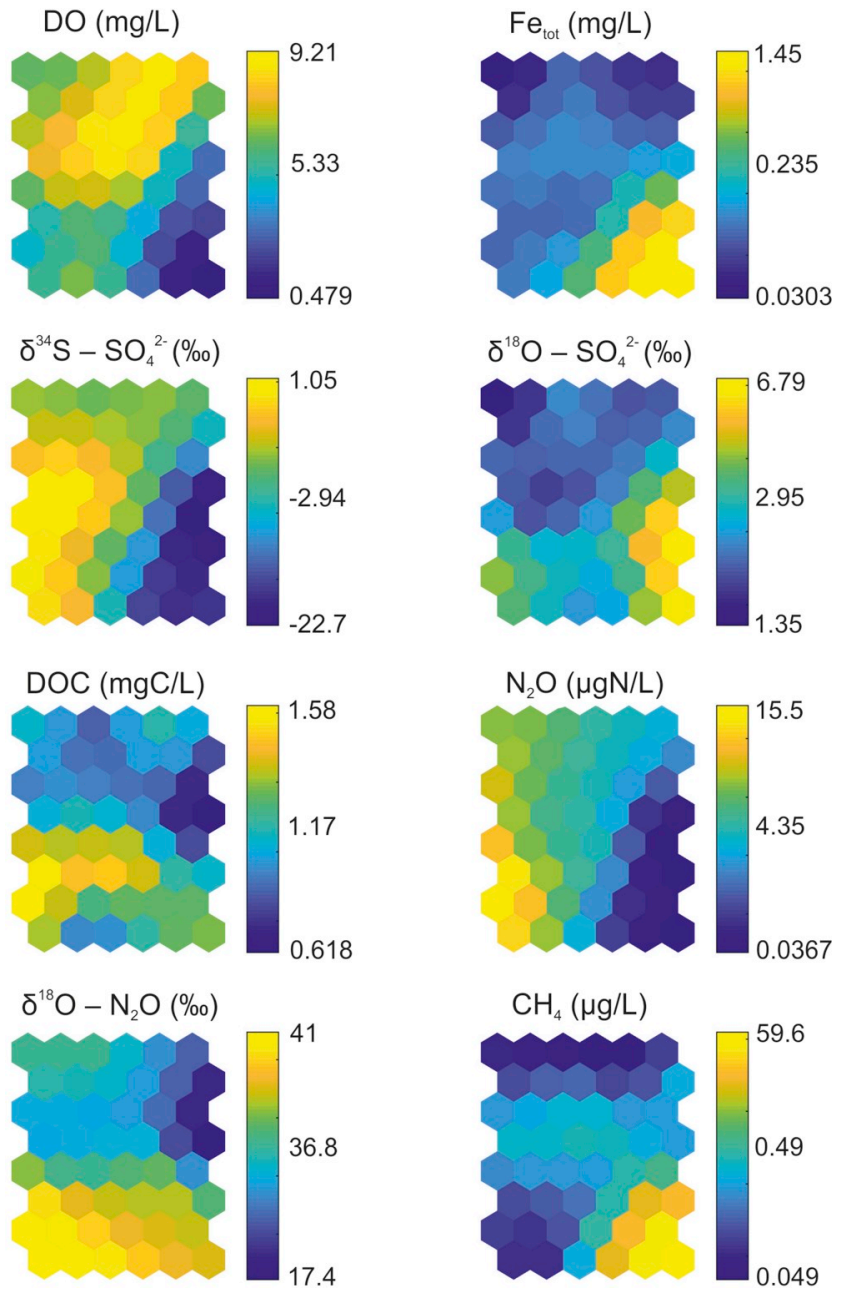
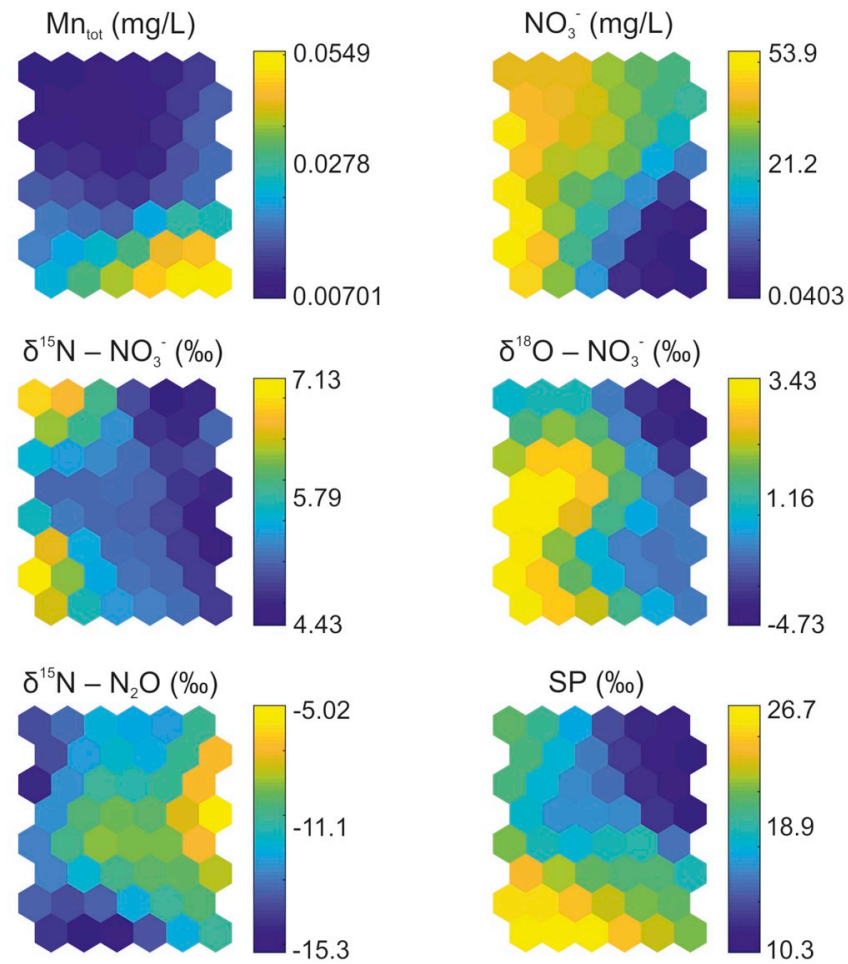

Fig. 5. The component matrices derived from the application of SOM procedure.

various clusters were analyzed using isotopomer maps in order to consider the probable occurrence of denitrification and nitrification.

Fig. 6 shows four different groups obtained by application of kmeans clustering on SOM. The dark blue (Group 1), green (Group 2) and blue (Group 3) groups include all of the groundwater samples collected from the unconfined part of the aquifer, while yellow group (Group 4) covers all of the studied points from the northern confined zone.

Group 1 includes locations in the unconfined zone which are characterized with the lowest SP (mean $11.2 \% 0 \pm 1.6 \%$ ), the lowest concentration of dissolved $\mathrm{N}_{2} \mathrm{O}$ (mean 3.5\% $\pm 1.2 \%$ ), high DO level (mean $8.2 \mathrm{mg} / \mathrm{L} \pm 1.9 \mathrm{mg} / \mathrm{L}$ ) and low $\mathrm{NO}_{3}{ }^{-}$(mean $28.7 \mathrm{mg}$ / $\mathrm{L} \pm 3.8 \mathrm{mg} / \mathrm{L}$ ). Group 2 corresponds to the highest SP (mean $26.1 \% 0 \pm 3.4 \%$ ), the highest concentration of $\mathrm{N}_{2} \mathrm{O}$ (mean $13.6 \%$ $\pm 6.3 \%$ ), the lowest amount of DO (mean $5.7 \mathrm{mg}$ / $\mathrm{L} \pm 2.4 \mathrm{mg} / \mathrm{L}$ ) and the highest concentration of $\mathrm{NO}_{3}{ }^{-}$(mean $48.7 \mathrm{mg}$ / $\mathrm{L} \pm 18.7 \mathrm{mg} / \mathrm{L}$ ). Group 3 demonstrates intermediate values of these parameters (see Table 1). Finally, Group 4 shows characteristic values for groundwater from the confined part of the aquifer, namely lowest concentrations of $\mathrm{NO}_{3}{ }^{-}$and DO (see section 3.1.1 and Table 3).

The majority of SP values are lower than typical SP for hydroxylamine $\left(\mathrm{NH}_{2} \mathrm{OH}\right)$ oxidation (nitrification) reported in previous studies. These data could support the hypothesis about the occurrence of both denitrification and nitrification processes with the following mixing of deep denitrified and shallow nitrified groundwater (which leads to the decrease in SP values produced by nitrification). To test this hypothesis, two isotopomer maps for the area of study (Figs. 7 and 8) were developed.
From the $\Delta \delta^{15} \mathrm{~N}_{\mathrm{NO}^{-}}{ }^{-}$- N2O (\%) versus SP (\%) isotopomer map (Fig. 7), it can be concluded that the majority of data points representing the isotopic signatures of respective samples in the southern, central and north-eastern zones fall into the mixing zone between nitrification and denitrification processes. Groundwater samples from Group 1 (points 17, 23 and 18) seem to be affected the most by denitrification in comparison to other samples, which is illustrated by their closer location to the denitrification box. However, in this group the denitrification in the deeper part of the aquifer was not complete, since Group 1 was characterized with the lowest $\mathrm{SP}$, and the $\mathrm{N}_{2} \mathrm{O}$ reduction to $\mathrm{N}_{2}$ produces SP values close to the ones caused by nitrification (Well et al., 2012). This hypothesis is also supported by the fact that the corresponding groundwater samples show high DO concentration (see Table 3), which would not be possible if mixing with anoxic waters $(<4 \mathrm{mg} / \mathrm{L})$ occurred.

The isotopic signatures of Group 2 (sampling points 30, 31 and 4) indicate mixing between nitrified groundwater and deep groundwater where complete denitrification occurred. The intensive denitrification processes are evidenced by the fact that all points fall outside the mixing zone (Fig. 7) and are shifted in the direction corresponding to typical $\mathrm{N}_{2} \mathrm{O}$ reduction. In addition, the lowest DO concentration was observed in this group.

In Group 3 (see Fig. 7), all samples are slightly shifted to the right of the mixing zone, suggesting mixing between nitrified and reduced groundwater. However, compared to Group 2, $\mathrm{N}_{2} \mathrm{O}$ reduction processes are probably less pronounced because of the high DO concentrations observed for groundwater samples from Group 3.

The second, $\delta^{15} \mathrm{~N}-\mathrm{N}_{2} \mathrm{O}$ (\%o v. AIR) versus $\delta^{18} \mathrm{O}-\mathrm{N}_{2} \mathrm{O}$ (\%o v. 


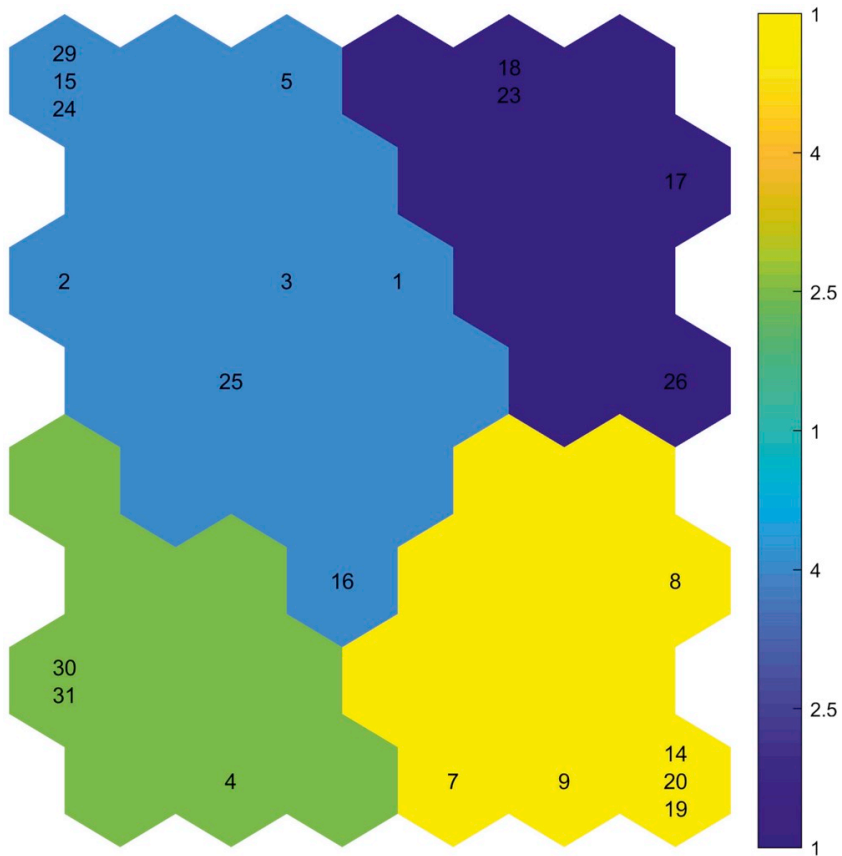

Fig. 6. Clustering of the groundwater samples using SOM algorithm. Group $1-$ dark blue, group 2 - green, group 3 - blue and group 4 - yellow. The numbers of sampled locations are presented within each of the group. (For interpretation of the references to colour in this figure legend, the reader is referred to the Web version of this article.)

Table 3

Mean hydrogeochemical parameters of the groundwater samples clusters produced by k-means clustering on SOM.

\begin{tabular}{lllll}
\hline Group & $\mathrm{N}_{2} \mathrm{O}(\mu \mathrm{g} \mathrm{N} / \mathrm{L})$ & $\mathrm{SP}(\%)$ & $\mathrm{DO}(\mathrm{mg} / \mathrm{L})$ & $\mathrm{NO}_{3}{ }^{-}(\mathrm{mg} / \mathrm{L})$ \\
\hline Group 1 & $3.4 \pm 1.2$ & $11.2 \pm 1.6$ & $8.2 \pm 1.9$ & $28.7 \pm 3.8$ \\
Group 2 & $13.6 \pm 6.3$ & $26.1 \pm 3.4$ & $5.7 \pm 2.4$ & $48.7 \pm 18.7$ \\
Group 3 & $6.7 \pm 3.4$ & $19.1 \pm 6.7$ & $7.2 \pm 2.6$ & $39.6 \pm 16.2$ \\
Group 4 & $0.1 \pm 0.1$ & not available & $1.5 \pm 2.1$ & $0.2 \pm 0.4$ \\
\hline
\end{tabular}

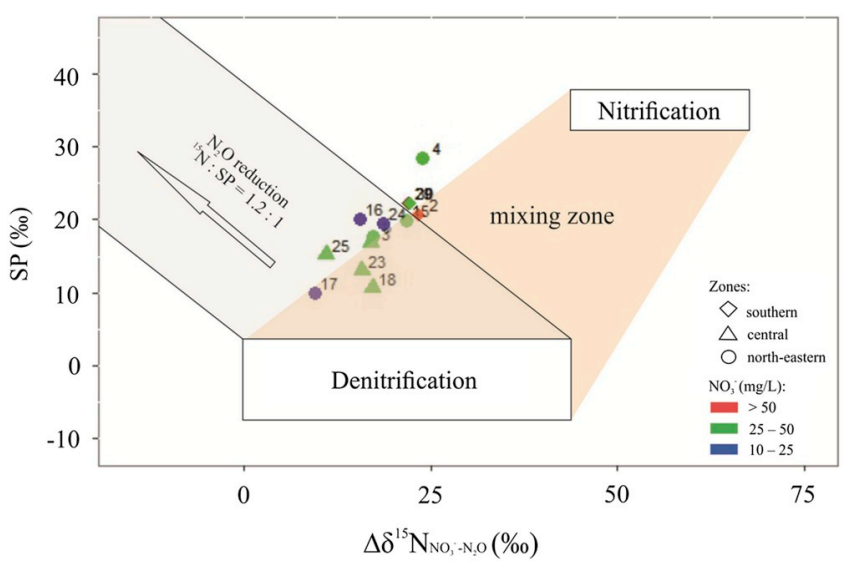

Fig. 7. $\Delta \delta^{15} \mathrm{~N}_{\mathrm{NO}^{-}}{ }^{-}$- 20 versus SP (\%) isotopomer map. The shape of the points shows affiliation to different zones presented in Fig. 1. Colors indicate different concentrations of $\mathrm{NO}_{3}{ }^{-}$in groundwater samples. (For interpretation of the references to colour in this figure legend, the reader is referred to the Web version of this article.)

VSMOW) (Fig. 8), isotope map provides further evidence supporting the hypothesis that groundwater from the unconfined part of the aquifer is affected by both nitrification and denitrification processes. The

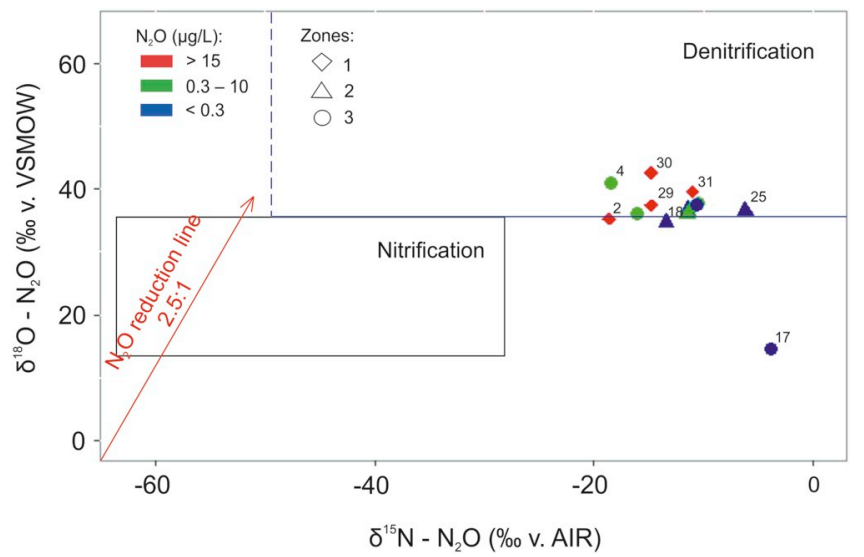

Fig. 8. $\delta^{15} \mathrm{~N}-\mathrm{N}_{2} \mathrm{O}$ (\%o v. AIR) versus $\delta^{18} \mathrm{O}-\mathrm{N}_{2} \mathrm{O}$ (\%o v. VSMOW) isotopomer map. The shape of the points shows affiliation to different zones presented in Fig. 1. Colors indicate different concentrations of $\mathrm{NO}_{3}{ }^{-}$in groundwater samples. (For interpretation of the references to colour in this figure legend, the reader is referred to the Web version of this article.)

majority of the samples fall close to the $\delta^{18} \mathrm{O}-\mathrm{N}_{2} \mathrm{O}$ value of $+35 \%$, reported to be the boundary value between nitrification and denitrification processes (Koba et al., 2009; Li et al., 2014).

Finally, in the northern zone, considering the low concentrations of $\mathrm{DO}$ and DOC as well as the data obtained from $\mathrm{SO}_{4}{ }^{2-}$ isotope analysis (Fig. 3), the occurrence of $\mathrm{N}_{2} \mathrm{O}$ could possibly be attributed to autotrophic (points 9 and 7) or heterotrophic (points 8, 14, 19 and 20) denitrification.

\subsection{2. $\mathrm{CH}_{4}$ production/consumption processes}

The chalk aquifer was characterized with high level of $\mathrm{CH}_{4}$ accumulation despite the fact that there were detected high concentrations of $\mathrm{DO}, \mathrm{NO}_{3}{ }^{-}$and $\mathrm{SO}_{4}{ }^{2-}$ in the unconfined part of the aquifer, and the high concentration of $\mathrm{SO}_{4}{ }^{2-}$ in the confined part of the aquifer (except point 14; Fig. S8 of the supporting information), which prohibits $\mathrm{CH}_{4}$ production.

In the northern confined zone, characterized with low concentration of DO and negligible content of $\mathrm{NO}_{3}{ }^{-}$, the concentration of $\mathrm{CH}_{4}$ was fifteen times higher in comparison to three other zones. At the same time, the concentration of $\mathrm{SO}_{4}{ }^{2-}$, which varied from $15 \mathrm{mg} / \mathrm{L}$ to $90 \mathrm{mg}$ / $\mathrm{L}$ within the confined area, might have prohibited $\mathrm{CH}_{4}$ production that usually occurs under lower $\mathrm{SO}_{4}{ }^{2-}$ concentrations $(<19 \mathrm{mg} / \mathrm{L})$ (Whiticar, 1999; Molofsky et al., 2016). Whiticar (1999) claimed that methanogenesis using non-competitive substances (e.g. methylated amines or dimethyl sulphide) might occur in the media where $\mathrm{SO}_{4}{ }^{2-}$ exists; however, their relative importance in $\mathrm{CH}_{4}$ production is currently uncertain. Therefore, the high values are more likely to be explained by its thermogenic origin or presence of anaerobic microsites with favorable conditions within the aquifer.

The concentration of $\mathrm{CH}_{4}$ in the groundwater samples from southern, central and north-eastern zones could be explained by occurrence of methanogenesis in the deeper part of the aquifer with the following mixing of deep $\mathrm{CH}_{4}$-enriched and shallow oxic water, which happened during the pumping activities. Moreover, the origin of $\mathrm{CH}_{4}$ in the deeper part of the aquifer might be related to its upward migration via geological faults and fracture networks from the Houiller formations enriched in coal. This last assumption could be supported by previous investigations conducted by the Hydrogeology and Environmental Geology group of the University of Liege in 2015 which showed high accumulation of radon $\left(28945 \mathrm{~Bq} / \mathrm{m}^{3}\right)$ in the deepest part of the aquifer at Bovenistier which might be the evidence of its origin from the underlying layers. Consequently, this observation suggests the possibility of gases diffusion through the smectite clay layer which was previously 
considered impermeable.

In general, additional investigations are required in order to obtain better insight into the $\mathrm{CH}_{4}$ production pathways. It will be useful to obtain data about the isotopic composition of $\mathrm{CH}_{4}, \delta^{13} \mathrm{C}$-DIC and microbiological community, which have been used in many studies for the identification of $\mathrm{CH}_{4}$ origin (Teh et al., 2005; Molofsky et al., 2013; McPhillips et al., 2014; Currell et al., 2017; Iverach et al., 2017).

\subsection{3. $\mathrm{CO}_{2}$ production/consumption processes}

Groundwater in the chalk aquifer demonstrated a tendency towards accumulation of $\mathrm{CO}_{2}$. It is possible to suggest four pathways of the $\mathrm{CO}_{2}$ production in the subsurface, namely - rhizomicrobial and root respiration, microbial decomposition of soil organic matter, denitrification and, possibly, methane generation (Kuzyakov and Larionova, 2005).

First two processes lead to the production of $\mathrm{CO}_{2}$ in the soil and its leaching into the groundwater during the rainy periods. The occurrence of microbial decomposition was evidenced by the data obtained from $\mathrm{SO}_{4}{ }^{2-}$ isotope analysis and parameters of water chemistry. In particular, the observed $\mathrm{SO}_{4}{ }^{2-}$ isotope signals indicated the occurrence of mineralization processes in the subsurface, which under aerobic conditions produce $\mathrm{SO}_{4}{ }^{2-}$ and DOC (Mayer et al., 1995; Kellman and Hillaire-Marcel, 2003). However, according to the experimental data, the studied aquifer was characterized with low concentration of DOC in groundwater, which could be the consequence of its further oxidation to $\mathrm{CO}_{2}$ in the unsaturated or saturated zones (MacQuarrie et al., 2001). The assumption regarding occurrence of DOC decomposition was also supported by the obtained strong negative correlation between the concentration of DOC and $\delta^{13} \mathrm{C}$-DOC.

Since it was revealed that the aquifer was characterized with suitable conditions for the occurrence of denitrification and methanogenesis processes in its deeper anoxic part, their contribution to the $\mathrm{CO}_{2}$ production could also be considered.

However, as our study was conducted in the chalk aquifer, the amount of dissolved $\mathrm{CO}_{2}$ in the groundwater is strongly influenced by the calcium carbonate equilibrium. $\mathrm{CO}_{2}$, produced within or leaked to the aquifer, reacts with $\mathrm{H}_{2} \mathrm{O}$ to form $\mathrm{H}_{2} \mathrm{CO}_{3}$, a weak acid, which stimulates the dissolution of carbonate rocks. That is why, the initially produced concentration of $\mathrm{CO}_{2}$ will be altered by equilibration processes. In particular, saturation indexes (Text S1 of the supporting information) varied from -0.18 to 0.22 (mean $0.05 \pm 0.08$ ) for calcite and from -1.25 to -0.21 (mean $-0.71 \pm 0.23$ ) for dolomite, indicating that groundwater was in equilibrium with respect to the first mineral and undersaturated with respect to the second one (Table S1 of the supporting information) (Moore and Wade, 2013). This situation is attributed to the lower solubility of dolomite in comparison to calcite (Moore and Wade, 2013).

So, it appears that the latter two pathways of $\mathrm{CO}_{2}$ production governed the concentration of $\mathrm{CO}_{2}$ in the northern confined zone, while in southern, central and north-eastern unconfined zones the presence of $\mathrm{CO}_{2}$ was determined by the simultaneous occurrence of all processes discussed in this section.

\subsection{Biogeochemistry of $\mathrm{N}_{2} \mathrm{O}, \mathrm{CH}_{4}$ and $\mathrm{CO}_{2}$. Vertical dimension}

\subsection{1. $\mathrm{N}_{2} \mathrm{O}$ production/consumption processes}

According to the obtained hydrogeochemical and isotope data, nitrification and denitrification could be observed at different depths along the vertical profile of the studied aquifer. Also, these data provide evidence that mixing processes between the deep and shallow groundwater and slow infiltration of pollutants from the surface to the deeper parts of the aquifer affected the distribution of GHGs within the subsurface.

The high concentrations of $\mathrm{DO}, \mathrm{NO}_{3}{ }^{-}$as well as $\delta^{15} \mathrm{~N}$ and $\delta^{18} \mathrm{O}$ isotopic signatures of $\mathrm{NO}_{3}{ }^{-}$at two shallowest piezometers at Bovenistier 28 and 27 (Table 2) provided the evidence of $\mathrm{N}_{2} \mathrm{O}$ production by nitrification processes. At the same time, the SP values of $\mathrm{N}_{2} \mathrm{O}$ at this site were considerably lower $(19.2 \% 0$ and $20 \%$, respectively) than SP typically reported for nitrification. The analysis of $\mathrm{SO}_{4}{ }^{2-}$ isotopes showed that this location was the only one where obtained values of isotopic composition of the deepest groundwater (26) clearly fell into the range typical for sulphide oxidation (Fig. 3), which might be associated with autotrophic denitrification (Jurado et al., 2018 b). Such evidence suggested that the isotopic signature of $\mathrm{N}_{2} \mathrm{O}$ of groundwater samples collected from the shallower part of the aquifer ( 28 and 27) was affected by both nitrification and denitrification processes (see section 3.1.2.).

The anaerobic conditions and distribution of ${ }^{15} \mathrm{~N}$ and ${ }^{18} \mathrm{O}$ isotopes of $\mathrm{NO}_{3}{ }^{-}$in the groundwater along vertical profile at Overhaem $(10,11$ and 12) (Table 2) suggested the occurrence of denitrification. Since the $\mathrm{SO}_{4}{ }^{2-}$ isotopes did not indicate the occurrence of sulphide oxidation (Fig. 3), the occurrence of heterotrophic denitrification could be a production mechanism of $\mathrm{N}_{2} \mathrm{O}$ in this location.

The high level of DO, relatively high concentrations of $\mathrm{NO}_{3}{ }^{-}$ (Table 2), results of $\mathrm{NO}_{3}{ }^{-}$and $\mathrm{SO}_{4}{ }^{2-}$ isotopes analyses (Figs. 2 and 3, respectively) at the SGB location $(21,22$ and 25$)$ indicated the occurrence of nitrification processes. The SP value of $\mathrm{N}_{2} \mathrm{O}$ at the shallowest 21 piezometer was equal to almost $32 \%$, which also supported the idea about ongoing nitrification (Toyoda et al., 2017). However, the SP values of the groundwater samples collected from the deeper SGB 3 and SGB 1 piezometers were $14.1 \%$ and $15.2 \%$, respectively. Such data indicated that the production of $\mathrm{N}_{2} \mathrm{O}$ might be the result of the simultaneous occurrence of both nitrification and denitrification or nitrifier-denitrification processes in the groundwater system at SGB site.

\subsection{2. $\mathrm{CH}_{4}$ production/consumption processes}

The concentration of $\mathrm{CH}_{4}$ (between $0.09 \mu \mathrm{g} / \mathrm{L}$ and $0.6 \mu \mathrm{g} / \mathrm{L}$ ) was higher than equilibrium with the atmosphere concentration in all locations across the vertical profile of the aquifer. However, no common trend in the distribution of $\mathrm{CH}_{4}$ with depth for Bovenistier, Overhaem and SGB sampling locations was revealed.

The only site which showed the suitable conditions for the in situ biological production of methane was the deepest sampling point at Bovenistier (Table 2). As for the Overhaem and SGB, the high concentrations of $\mathrm{NO}_{3}{ }^{-}, \mathrm{SO}_{4}{ }^{-}$and $\mathrm{DO}$ (only in case of SGB) along the whole depth interval excluded the possibility of methanogenesis. Therefore, detected co-existence of $\mathrm{CH}_{4}$ with considerable concentrations of $\mathrm{NO}_{3}{ }^{-}, \mathrm{SO}_{4}{ }^{2-}$ and $\mathrm{DO}$ might be the evidence of its thermogenic origin and vertical migration through the system of fractures, surface contamination or methanogenesis that occur in anoxic microsites within the aquifer.

\subsection{3. $\mathrm{CO}_{2}$ production/consumption processes}

The amount of $\mathrm{CO}_{2}$ varied noticeably within the vertical profile of the aquifer from the lowest concentrations in deep groundwater to the highest concentrations in the shallow groundwater. Such distribution might be explained by stronger effects of rainwater on the composition of shallow groundwater and the decrease in the microbial activity with depth. In particular, it is likely that rain water washes out the $\mathrm{CO}_{2}$ produced in the soil due to the decomposition of DOC (see section 4.2.3.) and root respiration (Tan, 2010).

\section{Conclusions}

In this study the distribution of GHGs within the chalk aquifer under agricultural area was explored both across lateral and vertical dimensions. Lateral studies focused on the variability of GHGs concentrations taking into account the differences in hydrogeology, hydrogeochemistry and urbanization level across the explored region. Vertical dimension investigations attempted to elucidate the impact of heterogeneity of aquifer conditions along the depth profile on GHG concentrations. 
Lateral explorations showed that among the three major GHGs it was the amount of $\mathrm{N}_{2} \mathrm{O}$, which exhibited the greatest cross-zonal variability between identified zones with contrasting environmental settings. The highest concentration of $\mathrm{N}_{2} \mathrm{O}$ was detected in the unconfined aerobic part of the aquifer under most urbanized area where the concentration of $\mathrm{NO}_{3}{ }^{-}$was the highest, while the lowest $\mathrm{N}_{2} \mathrm{O}$ content was measured in the confined anaerobic zone with the very low or almost absent $\mathrm{NO}_{3}{ }^{-}$and/or $\mathrm{NH}_{4}{ }^{+}$concentrations in the groundwater. In the zone of groundwater discharge to the Geer River, the average concentration of $\mathrm{N}_{2} \mathrm{O}$ was of the same magnitude as in the central zone, despite the fact that the $\mathrm{NO}_{3}{ }^{-}$content there was the lowest within the unconfined part of the aquifer. Also, in this zone the content of $\mathrm{N}_{2} \mathrm{O}$ varied significantly between different locations, as well as the level of DO, implying that the availability of $\mathrm{N}_{2} \mathrm{O}$ was governed by complex spatially heterogeneous pattern of different biogeochemical processes.

$\mathrm{CH}_{4}$ revealed the high tendency towards the accumulation in groundwater. Its concentration was substantially higher in the northern confined zone in comparison to three other zones. However, even in the unconfined southern, central and north-eastern zones despite the oxic conditions and presence of electron acceptors with higher energy yield the concentration of $\mathrm{CH}_{4}$ was, in average, approximately 13 times higher than its equilibrium atmospheric concentration.

Though the concentration of $\mathrm{CO}_{2}$ was high in comparison to its equilibrium concentration in the ambient air, it fluctuated less in comparison to $\mathrm{N}_{2} \mathrm{O}$ and $\mathrm{CH}_{4}$ concentrations. $\mathrm{CO}_{2}$ detected in the subsurface derived from root respiration or decomposition of organic matter. However, the relative uniformity of its spatial distribution is mostly attributed to the fact that in general the amount of $\mathrm{CO}_{2}$ dissolved in the groundwater was controlled by the process of dissolution of carbonate minerals which constitute aquifer geology.

The spatial differences in hydrogeochemical settings considerably influenced the dynamics of transformation of $\mathrm{N}$ and $\mathrm{C}$ loading in the subsurface, thus making tangible impact on the magnitude of the resulting indirect GHGs fluxes occurring on the groundwater-surface water interface. It was particularly noticeable in the case of highly volatile $\mathrm{N}_{2} \mathrm{O}$ production/consumption processes. The production of detected $\mathrm{N}_{2} \mathrm{O}$ could be attributed to a combination of nitrification and denitrification processes, likely occurring at different depths. However, the observed isotopic signals of $\mathrm{N}_{2} \mathrm{O}$ demonstrated that the intensity of these processes as well as their relative contribution to the concentration of $\mathrm{N}_{2} \mathrm{O}$ in the groundwater varied across different sampling locations.

Vertical dimension studies showed that different locations were characterized with different distribution pattern of major ions, GHGs and isotopes along the depth. However, in each of the cases they registered the shift in concentration of $\mathrm{CO}_{2}$ (decreasing with depth in all cases considered) and significant changes in both isotope signatures and concentration level of $\mathrm{N}_{2} \mathrm{O}$ across the depth profile. The latter observation indicated that production/consumption dynamics of $\mathrm{N}_{2} \mathrm{O}$ was highly dependent on the hydrogeochemistry of the ambient subsurface environment. It was revealed that the variability of chemical composition of groundwater in different locations was controlled by different biogeochemical processes changing in intensity with depth.

The observed heterogeneity of biogeochemical processes leading to GHGs production/consumption in the subsurface across the aquifer show that the magnitude of occurring GHGs fluxes (especially in the case of $\mathrm{N}_{2} \mathrm{O}$ in this study) could vary significantly due to the change in the amount of $\mathrm{N}$ and $\mathrm{C}$ inputs and distribution of their sources across different hydrogeochemical zones and in relation to groundwater flow pattern. Therefore, our study provides evidence to the assumption regarding existence of uncertainty of indirect GHGs fluxes related to upscaling of the point-derived estimations to the catchment level. In order to reduce this uncertainty, it is advised before the estimation of GHGs fluxes at the groundwater - river interface (and possible development of measures regulating their intensity) to take into account the insights obtained from larger-scale investigations in order to identify the representative spatial zones which shape the dynamics of GHGs emissions. As demonstrated by the results of combined application of SOM-derived clustering and interpretation of isotopomer maps, combination of insights from hydrogeochemical and isotope studies is essential in this regard, as it helps to get more profound insight into the process dynamics within the underground environment where the microbiological structure and aquifer matrix might be additional factors that affect the transformation of $\mathrm{N}$ and $\mathrm{C}$ compounds. Moreover, due to the high heterogeneity of $\mathrm{N}$ and $\mathrm{C}$ sources and subsurface processes, it is particularly important to pay attention to the biogeochemical processes and modeling of GHGs transport in the hyporheic zone, since this zone is the buffer controlling the highly volatile dynamics of GHGs fluxes at the groundwater-river interface. In addition, further research efforts within the case study area are necessary in order to better understand the influence of fluctuating piezometric levels on the dynamics of hydrogeochemical processes and GHGs production/consumption.

\section{Declarations of interest}

None.

\section{Acknowledgments}

This project has received funding from the European Union's Horizon 2020 research and innovation programme under the Marie Skłodowska-Curie grant agreement No 675120. A.V.B. is a senior research associate the Fonds National de la Recherche Scientifique. Tanguy Robert is a F.R.S.-FNRS postdoctoral researcher.

\section{Appendix A. Supplementary data}

Supplementary data to this article can be found online at https:// doi.org/10.1016/j.apgeochem.2019.04.009.

\section{References}

Aelion, C.M., Höhener, P., Hunkeler, D., Aravena, R. (Eds.), 2009. Environmental Isotopes in Biodegradation and Bioremediation. CRC Press.

Anderson, T.R., Groffman, P.M., Kaushal, S.S., Walter, M.T., 2014. Shallow groundwater denitrification in riparian zones of a headwater agricultural landscape. J. Environ. Qual. 43 (2), 732-744.

Battin, T.J., Luyssaert, S., Kaplan, L.A., Aufdenkampe, A.K., Richter, A., Tranvik, L.J., 2009. The boundless carbon cycle. Nat. Geosci. 2 (9), 598.

Beaulieu, J.J., Tank, J.L., Hamilton, S.K., Wollheim, W.M., Hall, R.O., Mulholland, P.J., et al., 2011. Nitrous oxide emission from denitrification in stream and river networks. Proc. Natl. Acad. Sci. Unit. States Am. 108 (1), 214-219.

Bell, R.A., Darling, W.G., Ward, R.S., Basava-Reddi, L., Halwa, L., Manamsa, K., Dochartaigh, B.Ó., 2017. A baseline survey of dissolved methane in aquifers of Great Britain. Sci. Total Environ. 601, 1803-1813.

Borges, A.V., Darchambeau, F., Teodoru, C.R., Marwick, T.R., Tamooh, F., Geeraert, N., et al., 2015. Globally significant greenhouse-gas emissions from African inland waters. Nat. Geosci. 8 (8), 637.

Boulvain, F., Pingot, J.L., 2008. Une introduction à la géologie de la Wallonie.

Brouyère, S., Dassargues, A., Hallet, V., 2004. Migration of contaminants through the unsaturated zone overlying the Hesbaye chalky aquifer in Belgium: a field investigation. J. Contam. Hydrol. 72 (1-4), 135-164.

Bunnell-Young, D., Rosen, T., Fisher, T.R., Moorshead, T., Koslow, D., 2017. Dynamics of nitrate and methane in shallow groundwater following land use conversion from agricultural grain production to conservation easement. Agric. Ecosyst. Environ. 248, 200-214.

Butterbach-Bahl, K., Well, R., 2010. Indirect emissions of nitrous oxide from nitrogen deposition and leaching of agricultural nitrogen. In: Nitrous Oxide and Climate Change. Routledge, pp. 166-193.

Casciotti, K.L., Sigman, D.M., Ward, B.B., 2003. Linking diversity and stable isotope fractionation in ammonia-oxidizing bacteria. Geomicrobiol. J. 20 (4), 335-353.

Casciotti, K.L., McIlvin, M., Buchwald, C., 2010. Oxygen isotopic exchange and fractionation during bacterial ammonia oxidation. Limnol. Oceanogr. 55 (2), 753-762.

Choi, B.Y., Yun, S.T., Mayer, B., Chae, G.T., Kim, K.H., Kim, K., Koh, Y.K., 2010. Identification of groundwater recharge sources and processes in a heterogeneous alluvial aquifer: results from multi-level monitoring of hydrochemistry and environmental isotopes in a riverside agricultural area in Korea. Hydrol. Process. 24 (3), 317-330.

Clagnan, E., Thornton, S.F., Rolfe, S.A., Tuohy, P., Peyton, D., Wells, N.S., Fenton, O., 
2018. Influence of artificial drainage system design on the nitrogen attenuation potential of gley soils: evidence from hydrochemical and isotope studies under fieldscale conditions. J. Environ. Manag. 206, 1028-1038.

Clough, T.J., Addy, K., Kellogg, D.Q., Nowicki, B.L., Gold, A.J., Groffman, P.M., 2007. Dynamics of nitrous oxide in groundwater at the aquatic-terrestrial interface. Glob. Chang. Biol. 13, 1528-1537.

Cooper, R.J., Wexler, S.K., Adams, C.A., Hiscock, K.M., 2017. Hydrogeological controls on regional-scale indirect nitrous oxide emission factors for rivers. Environ. Sci. Technol. 51 (18), 10440-10448.

Currell, M., Banfield, D., Cartwright, I., Cendón, D.I., 2017. Geochemical indicators of the origins and evolution of methane in groundwater: Gippsland Basin, Australia. Environ. Sci. Pollut. Control Ser. 24 (15), 13168-13183.

Dautrebande, S., Sohier, C., 2004. Modélisation hydrologique des sols et des pratiques agricoles en Région wallonne (Sous-bassins de la Meuse et de l'Escaut). Faculté des Sciences Agronomiques de Gembloux, Unité d'Hydraulique Agricole.

Denman, S.E., Tomkins, N.W., McSweeney, C.S., 2007. Quantitation and diversity analysis of ruminal methanogenic populations in response to the antimethanogenic compound bromochloromethane. FEMS Microbiol. Ecol. 62 (3), 313-322.

Fitts, C.R., 2002. Groundwater Science. Elsevier.

Gamble, A., Babbar-Sebens, M., 2012. On the use of multivariate statistical methods for combining in-stream monitoring data and spatial analysis to characterize water quality conditions in the White River Basin, Indiana, USA. Environ. Monit. Assess. 184 (2), 845-875.

Goderniaux, P., Brouyere, S., Blenkinsop, S., Burton, A., Fowler, H.J., Orban, P., Dassargues, A., 2011. Modeling climate change impacts on groundwater resources using transient stochastic climatic scenarios. Water Resour. Res. 47 (12).

Hakoun, V., Orban, P., Dassargues, A., Brouyère, S., 2017. Factors controlling spatial and temporal patterns of multiple pesticide compounds in groundwater (Hesbaye chalk aquifer, Belgium). Environ. Pollut. 223, 185-199.

Hasegawa, K., Hanaki, K., Matsuo, T., Hidaka, S., 2000. Nitrous oxide from the agricultural water system contaminated with high nitrogen. Chemosphere Global Change Sci. 2 (3), 335-345.

Hérivaux, C., Orban, P., Brouyère, S., 2013. Is it worth protecting groundwater from diffuse pollution with agri-environmental schemes? A hydro-economic modeling approach. J. Environ. Manag. 128, 62-74.

Hiscock, K.M., Bateman, A.S., Mühlherr, I.H., Fukada, T., Dennis, P.F., 2003. Indirect emissions of nitrous oxide from regional aquifers in the United Kingdom. Environ. Sci. Technol. 37 (16), 3507-3512.

IPCC, 2013. In: Stocker, T.F., Qin, D., Plattner, G.-K., Tignor, M., Allen, S.K., Boschung, J., Nauels, A., Xia, Y., Bex, V., Midgley, P.M. (Eds.), Climate Change 2013: the Physical Science Basis. Contribution of Working Group I to the Fifth Assessment Report of the Intergovernmental Panel on Climate Change. Cambridge University Press, Cambridge, United Kingdom and New York, NY, USA, pp. 1535. https://doi.org/10. $1017 / \mathrm{CBO} 9781107415324$.

Iverach, C.P., Beckmann, S., Cendón, D.I., Manefield, M., Kelly, B.F., 2017. Biogeochemical constraints on the origin of methane in an alluvial aquifer: evidence for the upward migration of methane from underlying coal measures. Biogeosciences 14 (1), 215-228.

Jahangir, M.M., Khalil, M.I., Johnston, P., Cardenas, L.M., Hatch, D.J., Butler, M., et al., 2012. Denitrification potential in subsoils: a mechanism to reduce nitrate leaching to groundwater. Agric. Ecosyst. Environ. 147, 13-23.

Jahangir, M.M.R., Johnston, P., Barret, M., Khalil, M.I., Groffman, P.M., Boeckx, P., Richards, K.G., 2013. Denitrification and indirect N2O emissions in groundwater: hydrologic and biogeochemical influences. J. Contam. Hydrol. 152, 70-81.

Johnson, M.S., Lehmann, J., Riha, S.J., Krusche, A.V., Richey, J.E., Ometto, J.P.H., Couto, E.G., 2008. CO2 efflux from Amazonian headwater streams represents a significant fate for deep soil respiration. Geophys. Res. Lett. 35 (17).

Jurado, A., Borges, A.V., Brouyère, S., 2017. Dynamics and emissions of N2O in groundwater: a review. Sci. Total Environ. 584, 207-218.

Jurado, A., Borges, A.V., Pujades, E., Briers, P., Nikolenko, O., Dassargues, A., Brouyère, S., 2018a. Dynamics of greenhouse gases in the river-groundwater interface in a gaining river stretch (Triffoy catchment, Belgium). Hydrogeol. J. 26 (8), 2739-2751.

Jurado, A., Borges, A.V., Pujades, E., Hakoun, V., Otten, J., Knöller, K., Brouyère, S., 2018b. Occurrence of greenhouse gases in the aquifers of the Walloon Region (Belgium). Sci. Total Environ. 619, 1579-1588.

Kellman, L.M., Hillaire-Marcel, C., 2003. Evaluation of nitrogen isotopes as indicators of nitrate contamination sources in an agricultural watershed. Agric. Ecosyst. Environ. 95 (1), 87-102.

Kindler, R., Siemens, J., Kaiser, K., Walmsley, D.C., Bernhofer, C., Buchmann, et al., 2011. Dissolved carbon leaching from soil is a crucial component of the net ecosystem carbon balance. Glob. Chang. Biol. 17 (2), 1167-1185.

Knöller, K., Trettin, R., Strauch, G., 2005. Sulphur cycling in the drinking water catchment area of Torgau-Mockritz (Germany): insights from hydrochemical and stable isotope investigations. Hydrol. Process. 19 (17), 3445-3465.

Koba, K., Osaka, K., Tobari, Y., Toyoda, S., Ohte, N., Katsuyama, M., et al., 2009. Biogeochemistry of nitrous oxide in groundwater in a forested ecosystem elucidated by nitrous oxide isotopomer measurements. Geochem. Cosmochim. Acta 73 (11), 3115-3133.

Krouse, H.R., Mayer, B., 2000. Sulphur and oxygen isotopes in sulphate. In: Environmental Tracers in Subsurface Hydrology. Springer, Boston, MA, pp. 195-231.

Kroeze, C., Dumont, E., Seitzinger, S.P., 2005. New estimates of global emissions of N2O from rivers and estuaries. Environ. Sci. 2 (2-3), 159-165.

Kuzyakov, Y., Larionova, A.A., 2005. Root and rhizomicrobial respiration: a review of approaches to estimate respiration by autotrophic and heterotrophic organisms in soil. J. Plant Nutr. Soil Sci. 168 (4), 503-520.

Laini, A., Bartoli, M., Castaldi, S., Viaroli, P., Capri, E., Trevisan, M., 2011. Greenhouse gases (CO2, CH4 and N2O) in lowland springs within an agricultural impacted watershed (Po River Plain, northern Italy). Chem. Ecol. 27 (2), 177-187.

Lewicka-Szczebak, D., Augustin, J., Giesemann, A., Well, R., 2017. Quantifying N2O reduction to N2 based on $\mathrm{N} 2 \mathrm{O}$ isotopocules-validation with independent methods (helium incubation and 15N gas flux method). Biogeosciences 14 (3), 711.

Li, L., Spoelstra, J., Robertson, W.D., Schiff, S.L., Elgood, R.J., 2014. Nitrous oxide as an indicator of nitrogen transformation in a septic system plume. J. Hydrol. 519, 1882-1894.

MacQuarrie, K.T., Sudicky, E.A., Robertson, W.D., 2001. Multicomponent simulation of wastewater-derived nitrogen and carbon in shallow unconfined aquifers: II. Model application to a field site. J. Contam. Hydrol. 47 (1), 85-104.

Macpherson, G.L., 2009. CO2 distribution in groundwater and the impact of groundwater extraction on the global C cycle. Chem. Geol. 264 (1-4), 328-336.

Mayer, B., Fritz, P., Prietzel, J., Krouse, H.R., 1995. The use of stable sulfur and oxygen isotope ratios for interpreting the mobility of sulfate in aerobic forest soils. Appl. Geochem. 10 (2), 161-173.

Mayer, B., 2005. Assessing sources and transformations of sulphate and nitrate in the hydrosphere using isotope techniques. In: Isotopes in the Water Cycle. Springer Netherlands, pp. 67-89.

McMahon, P.B., Böhlke, J.K., 2006. Regional patterns in the isotopic composition of natural and anthropogenic nitrate in groundwater, High Plains, USA. Environ. Sci. Technol. 40 (9), 2965-2970.

McPhillips, L.E., Creamer, A.E., Rahm, B.G., Walter, M.T., 2014. Assessing dissolved methane patterns in central New York groundwater. J. Hydrol.: Reg. Stud. 1, 57-73.

Michener, R., Lajtha, K. (Eds.), 2008. Stable Isotopes in Ecology and Environmental Science. John Wiley \& Sons.

Minamikawa, K., Nishimura, S., Sawamoto, T., Nakajima, Y., Yagi, K., 2010. Annual emissions of dissolved $\mathrm{CO} 2, \mathrm{CH} 4$, and $\mathrm{N} 2 \mathrm{O}$ in the subsurface drainage from three cropping systems. Glob. Chang. Biol. 16 (2), 796-809.

Minamikawa, K., Nishimura, S., Nakajima, Y., Osaka, K.I., Sawamoto, T., Yagi, K., 2011. Upward diffusion of nitrous oxide produced by denitrification near shallow groundwater table in the summer: a lysimeter experiment. Soil Sci. Plant Nutr. 57 (5), 719-732.

Minet, E.P., Goodhue, R., Meier-Augenstein, W., Kalin, R.M., Fenton, O., Richards, K.G., Coxon, C.E., 2017. Combining stable isotopes with contamination indicators: a method for improved investigation of nitrate sources and dynamics in aquifers with mixed nitrogen inputs. Water Res. 124, 85-96.

Molofsky, L.J., Connor, J.A., Wylie, A.S., Wagner, T., Farhat, S.K., 2013. Evaluation of methane sources in groundwater in northeastern Pennsylvania. Gr. Water 51 (3), 333-349.

Molofsky, L.J., Connor, J.A., McHugh, T.E., Richardson, S.D., Woroszylo, C., Alvarez, P.J., 2016. Environmental factors associated with natural methane occurrence in the Appalachian Basin. Gr. Water 54 (5), 656-668.

Moore, C.H., Wade, W.J., 2013. Concepts of sequence stratigraphy as applied to carbonate depositional systems. In: Carbonate Reservoirs: Porosity and Diagenesis in a Sequence Stratigraphic Framework, vol. 67. Newnes, pp. 19-36.

Morana, C., Darchambeau, F., Roland, F.A.E., Borges, A.V., Muvundja, F., Kelemen, Z., et al., 2015. Biogeochemistry of a large and deep tropical lake (Lake Kivu, East Africa: insights from a stable isotope study covering an annual cycle). Biogeosciences 12 (16), 4953-4963.

Mosier, A., Kroeze, C., Nevison, C., Oenema, O., Seitzinger, S., Van Cleemput, O., 1998. Closing the global N2O budget: nitrous oxide emissions through the agricultural nitrogen cycle. Nutrient Cycl. Agroecosyst. 52 (2-3), 225-248.

Nikolenko, O., Jurado, A., Borges, A.V., Knöller, K., Brouyère, S., 2017. Isotopic composition of nitrogen species in groundwater under agricultural areas: a review. Sci. Total Environ. 621, 1415-1432.

Orban, P., Batlle-Aguilar, J., Goderniaux, P., Dassargues, A., Brouyère, S., 2006 Description of Hydrogeological Conditions in the Geer Sub-catchment and Synthesis of Available Data for Groundwater Modelling. Deliverable R3.16, AquaTerra (Integrated Project FP6 505428).

Orban, P., Brouyère, S., Batlle-Aguilar, J., Couturier, J., Goderniaux, P., Leroy, M., et al., 2010. Regional transport modelling for nitrate trend assessment and forecasting in a chalk aquifer. J. Contam. Hydrol. 118 (1-2), 79-93.

Ostrom, N.E., Pitt, A., Sutka, R., Ostrom, P.H., Grandy, A.S., Huizinga, K.M., Robertson, G.P., 2007. Isotopologue effects during N2O reduction in soils and in pure cultures of denitrifiers. J. Geophys. Res.: Biogeosciences 112 (G2).

Peeters, L., Bacao, R., Lobo, V., Dassargues, A., 2007. Exploratory data analysis and clustering of multivariate spatial hydrogeological data by means of GEO3DSOM, a variant of Kohonen's Self-Organizing Map. Hydrol. Earth Syst. Sci. 11 (4), 1309-1321.

Rosamond, M.S., 2013. N2O and NO3-In the Grand River: Sources, Production Pathways and Predictability. Doctoral Dissertation, Dissertation. University of Waterloo. .

Sigman, D.M., Casciotti, K.L., Andreani, M., Barford, C., Galanter, M.B.J.K., Böhlke, J.K., 2001. A bacterial method for the nitrogen isotopic analysis of nitrate in seawater and freshwater. Anal. Chem. 73 (17), 4145-4153.

Smith, K.A. (Ed.), 2010. Nitrous Oxide and Climate Change. Earthscan.

Snider, D.M., Schiff, S.L., Spoelstra, J., 2009. 15N/14N and 18O/16O stable isotope ratios of nitrous oxide produced during denitrification in temperate forest soils. Geochem. Cosmochim. Acta 73 (4), 877-888.

Snider, D.M., Venkiteswaran, J.J., Schiff, S.L., Spoelstra, J., 2012. Deciphering the oxygen isotope composition of nitrous oxide produced by nitrification. Glob. Chang. Biol. 18 (1), 356-370.

Snider, D.M., Venkiteswaran, J.J., Schiff, S.L., Spoelstra, J., 2013. A new mechanistic model of $8180-\mathrm{N} 2 \mathrm{O}$ formation by denitrification. Geochem. Cosmochim. Acta 112, $102-115$.

Sutka, R.L., Ostrom, N.E., Ostrom, P.H., Breznak, J.A., Gandhi, H., Pitt, A.J., Li, F., 2006. 
Distinguishing nitrous oxide production from nitrification and denitrification on the basis of isotopomer abundances. Appl. Environ. Microbiol. 72 (1), 638-644.

Syakila, A., Kroeze, C., 2011. The global nitrous oxide budget revisited. Greenh. Gas Meas. Manag. 1 (1), 17-26.

Tan, K.H., 2010. Principles of soil chemistry. CRC press.

Teh, Y.A., Silver, W.L., Conrad, M.E., 2005. Oxygen effects on methane production and oxidation in humid tropical forest soils. Glob. Chang. Biol. 11 (8), 1283-1297.

Toyoda, S., Yoshida, N., Koba, K., 2017. Isotopocule analysis of biologically produced nitrous oxide in various environments. Mass Spectrom. Rev. 36 (2), 135-160.

Vesanto, J., Himberg, J., Alhoniemi, E., Parhankangas, J., 2000. SOM Toolbox for Matlab 5. Helsinki University of Technology, Finland, pp. 109.

Vilain, G., Garnier, J., Tallec, G., Tournebize, J., 2012. Indirect N2O emissions from shallow groundwater in an agricultural catchment (Seine Basin, France). Biogeochemistry 111, 253-271.

von der Heide, C., Böttcher, J., Deurer, M., Weymann, D., Well, R., Duijnisveld, W.H.M., 2008. Spatial variability of N2O concentrations and of denitrification-related factors in the surficial groundwater of a catchment in Northern Germany. J. Hydrol. 360, 230-241.

Wassenaar, L.I., Douence, C., Altabet, M.A., Aggarwal, P.K., 2018. N and O isotope $(\delta 15 \mathrm{N \alpha}, \delta 15 \mathrm{~N} \beta, \delta 180, \delta 17 \mathrm{O})$ analyses of dissolved NO3 - and NO2 - by the Cdazide reduction method and N2O laser spectrometry. Rapid Commun. Mass Spectrom. 32 (3), 184-194.

Well, R., Eschenbach, W., Flessa, H., von der Heide, C., Weymann, D., 2012. Are dual isotope and isotopomer ratios of $\mathrm{N} 2 \mathrm{O}$ useful indicators for $\mathrm{N} 2 \mathrm{O}$ turnover during denitrification in nitrate-contaminated aquifers? Geochem. Cosmochim. Acta 90,
265-282.

Well, R., Flessa, H., Jaradat, F., Toyoda, S., Yoshida, N., 2005. Measurement of isotopomer signatures of $\mathrm{N}_{2} \mathrm{O}$ in groundwater. J. Geophys. Res. Biogeosci. 110 (G2).

Weymann, D., Well, R., Flessa, H., von der Heide, C., Deurer, M., Meyer, K., Walther, W. 2008. Groundwater N2O emission factors of nitrate contaminated aquifers as derived from denitrification progress and N2O accumulation. Biogeosciences 5, 1215-1226.

Whiticar, M.J., 1999. Carbon and hydrogen isotope systematics of bacterial formation and oxidation of methane. Chem. Geol. 161 (1-3), 291-314.

Widory, D., Kloppmann, W., Chery, L., Bonnin, J., Rochdi, H., Guinamant, J.L., 2004 Nitrate in groundwater: an isotopic multi-tracer approach. J. Contam. Hydrol. 72 (1-4), 165-188.

Wilcock, R.J., Sorrell, B.K., 2008. Emissions of greenhouse gases CH4 and N2O from lowgradient streams in agriculturally developed catchments. Water, Air, Soil Pollut. 188 (1-4), 155-170.

Worrall, F., Lancaster, A., 2005. The release of $\mathrm{CO} 2$ from riverwaters-the contribution of excess CO2 from groundwater. Biogeochemistry 76 (2), 299-317.

Xue, D., Botte, J., De Baets, B., Accoe, F., Nestler, A., Taylor, P., et al., 2009. Present limitations and future prospects of stable isotope methods for nitrate source identification in surface-and groundwater. Water Res. 43 (5), 1159-1170.

Yakovlev, V., Vystavna, Y., Diadin, D., Vergeles, Y., 2015. Nitrates in springs and rivers of East Ukraine: distribution, contamination and fluxes. Appl. Geochem. 53, 71-78.

Zou, Y., Hirono, Y., Yanai, Y., Hattori, S., Toyoda, S., Yoshida, N., 2014. Isotopomer analysis of nitrous oxide accumulated in soil cultivated with tea (Camellia sinensis) in Shizuoka, central Japan. Soil Biol. Biochem. 77, 276-291. 